\title{
A oferta residencial na retração imobiliária da metrópole paulistana nos anos 2000
}

\author{
Housing supply in the real estate downturn \\ of the São Paulo metropolis in the 2000 s
}

Carolina Maria Pozzi de Castro [I] Letícia Moreira Sígolo [II]

\begin{abstract}
Resumo
A análise identifica mudanças e continuidades no comportamento da oferta residencial na retração imobiliária da Região Metropolitana de São Paulo nos anos 2000. Estrutura-se uma periodização, considerando movimentos macroeconômicos e seus impactos no setor imobiliário. Observam-se dinâmicas baseadas em subtipos de mercado e vetores de expansão da oferta, refletindo especificidades e rugosidades no território metropolitano, além das características dos lançamentos e sua precificação balizada nos financiamentos disponíveis e estratégias de maximização de ganhos dos incorporadores. Verifica-se um reposicionamento do setor em que o mercado da Capital assume centralidade nas estratégias que regionalmente contrarrestam a crise com oferta importante de produtos econômicos e alterações nos padrões, apoiada no Programa Minha Casa Minha Vida, mediante crescente participação de grandes empresas.
\end{abstract}

Palavras-chave: mercado imobiliário; oferta residencial; retração; Região Metropolitana de São Paulo.

\begin{abstract}
The analysis identifies changes and continuities in the behavior of housing supply in the real estate downturn of the São Paulo Metropolitan Region in the 2000s. It is structured on a periodization, considering macroeconomic movements and their impacts on the real estate sector. We observed dynamics based on market subtypes and on supply expansion vectors, reflecting specificities and the roughness of the metropolitan territory. In addition, we surveyed the characteristics of housing launches and their pricing based on the available financing and on strategies to maximize developers' gains. There is a repositioning of the sector as the capital city's market is prioritized by strategies that regionally counteract the crisis through an important supply of affordable housing and pattern changes, supported by the Minha Casa Minha Vida housing program, with an increasing participation of large companies.
\end{abstract}

Keywords: real estate market; housing supply; downturn; Metropolitan Region of São Paulo. 


\section{Introdução: por que estudar a oferta residencial na RMSP?}

\author{
A Região Metropolitana de São Paulo (RMSP) ${ }^{1}$ \\ é o centro do sistema financeiro-imobiliário \\ nacional, no qual estão presentes diferentes ti-
} pos de mercados, como o mercado residencial (formal e informal, de aquisição e de locação) e seus diferentes subtipos, que atuam de forma articulada, complementar e interdependente, e em diferentes escalas. Em que pese a permanência da lógica patrimonialista, o avanço da dominância financeira na produção do espaço, por meio do entrelaçamento das empresas do setor imobiliário com o mercado de capitais e da transformação da terra em ativo financeiro, produz alterações profundas nos circuitos da acumulação urbana e em suas formas de extração da renda, que se manifestam na escala da produção, nas estratégias locacionais das empresas, na capacidade de orquestração das condições de maximização dos ganhos (Ribeiro, 2020; Maricato, 2011a; Rolnik, 2015; Rufino, 2019). E tais movimentos se exacerbam na metrópole.

A produção do espaço metropolitano pelo setor imobiliário torna-se mercadoria reprodutível, e seus processos constitutivos acarretam a tendência de homogeneização considerando a repetição de estruturas urbanas e de consumo do espaço. Enquanto movimento contraditório, essa homogeneização se manifesta de forma também fragmentada, correspondendo a estruturas segregadoras ancoradas pela propriedade privada da terra (Lefebvre, 1973; Carlos, 2007).

A RMSP, que compreende uma rede de cidades com polaridades diferenciadas, apresenta um mercado residencial de alta complexidade e multiescalar, com vultosa produção de valor e reprodução continuada de espaço-mercadoria. Permeado de conflitos e disputas, tem sido definido por um grande dinamismo resultante da convergência de abundantes e diversificadas demandas e fluxos intensos de recursos para financiamento à produção e à aquisição, além de conduzido por variados arranjos e alianças entre frações do capital no circuito de acumulação em que se inserem as estruturas de provisão, que aglutinam empresas locais, regionais, nacionais e globais (Ball, 1986).

Esse movimento ganha escala e robustez pela elevada concentração dos investimentos nos circuitos imobiliários da metrópole paulistana, tornando-a um objeto bastante propício ao conjunto das análises elaboradas neste artigo. Cumpre observar que esse dinamismo é suscetível aos movimentos da macroeconomia, potencializado e restringido a depender das políticas nacionais adotadas em cada período. Nos anos aqui analisados, de desaceleração e retração da oferta, um menor dinamismo foi consequência do esgotamento das políticas anticíclicas e da adoção de políticas de austeridade fiscal ao longo da década de 2010, acompanhada pela redução nos rendimentos e na capacidade de consumo dos brasileiros, impondo, em âmbito nacional, uma crise severa à produção imobiliária, e exigiu um reposicionamento do setor, no qual a RMSP, sobretudo o município de São Paulo (MSP), assume grande centralidade no conjunto das estratégias que visam a contrarrestar os efeitos da retração e a impulsionar a recuperação amparada por mudanças importantes na moldura institucional (Mioto e Penha Filho, 2018; Mioto, Castro e Sígolo, 2019). Os impactos dessa retração e seus contornos na RMSP são o objeto da análise aqui apresentada. 
Assim, a questão central desta pesquisa é direcionada à compreensão das mudanças e das continuidades na oferta residencial no período da retração na RMSP, fundamentada nas condições do financiamento, tendo em vista sua localização, volume e distribuição, as características e os padrões dos produtos lançados, bem como as estratégias das empresas do setor imobiliário. Adota-se uma periodização em diálogo com os movimentos da macroeconomia e dinâmicas setoriais, organizada por triênios, buscando caracterizar intervalos de tempos consoantes à expansão, desaceleração e retração da oferta residencial na região, e atenta às relevantes repercussões decorrentes da dependência direta da incorporação à disponibilização do funding e da capacidade de endividamento/solvabilidade da demanda (Silva, 2015).

Desse modo, são construídas categorias de análise para a interpretação da distribuição dos lançamentos no território metropolitano, constituído por municípios, além das subprefeituras do MSP. ${ }^{2}$ Essas categorias versam sobre duas dimensões: uma voltada à análise de subtipos de mercado, que são detalhados por preços e volumes ofertados; e outra, à identificação e à leitura das dinâmicas vetoriais da oferta, reconhecendo especificidades e rugosidades territoriais, além de elementos da estrutura urbana que são cotejados com mapas de localização e distribuição dos lançamentos residenciais no triênio estudado.

Também é elaborada uma caracterização geral da oferta residencial a partir de informações extraídas do banco de dados da Embraesp, referentes ao conjunto dos lançamentos residenciais, sistematizadas por ano e/ou triênio, que permitem identificar o padrão/porte/tipologia dos empreendimentos e/ou unidades e a precificação dos produtos lançados, assumindo como referência os tetos dos financiamentos disponíveis, relacionando-os aos perfis de agentes promotores intervenientes (incorporadoras) com foco em suas participações no mercado da RMSP.

Neste estudo, adota-se, como definição de segmento econômico, o conjunto da oferta de unidades com preços enquadrados no intervalo de até US\$100 mil, equivalentes a R\$350 mil, em 2015 (Castro e Shimbo, 2011). A partir de 2009, os desdobramentos evidenciados na oferta do segmento econômico apontaram a existência de dois estratos: um deles relativo aos produtos nas faixas 2 e 3 do Programa Minha Casa Minha Vida (PMCMV); ${ }^{3} \mathrm{e}$ o outro, acima dos tetos desse Programa, até US\$100 mil/R\$350 mil. Pela importância do segmento econômico no contexto da retração na RMSP, sobretudo no MSP, aprofunda-se na caracterização dessa oferta na busca de desvelar a inserção intensificada desses produtos no mercado da Capital.

\section{Mudanças e continuidades na retração da oferta residencial na RMSP: volume, localização e distribuição}

Considerando o volume, a localização e a distribuição da oferta na RMSP, no período da retração (2016-2018), são identificados dois movimentos distintos e complementares, 
Gráfico 1 - Número de unidades residenciais lançadas por ano na RMSP

(2010 a 2018)

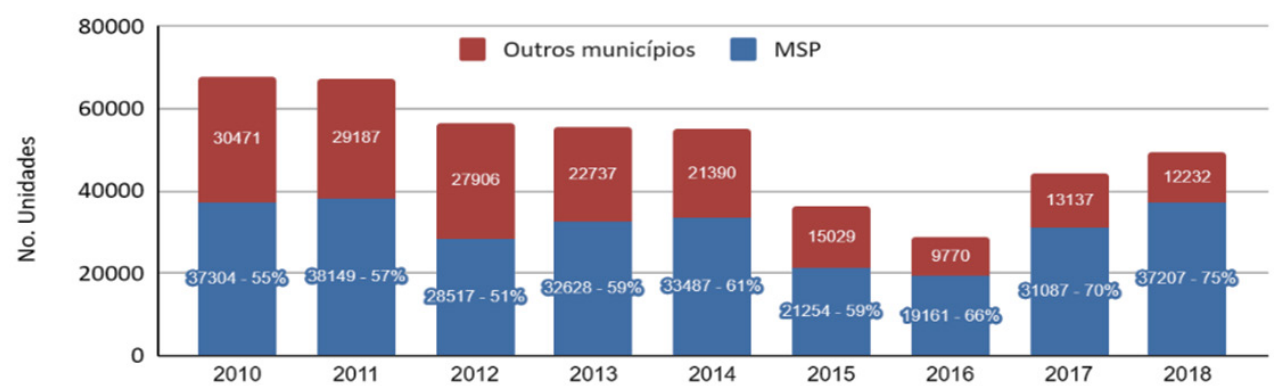

Fonte: Embraesp (2018).

após o reposicionamento setorial em resposta à queda do crescimento da economia nacional (Mioto, Castro e Sígolo, 2019): o crescimento do volume e participação do MSP no conjunto das unidades (UHs) lançadas enquanto há redução acentuada fora da Capital. Em 2018, a participação do MSP nas unidades lançadas na RMSP, de 75\%, é semelhante à do ano anterior à expansão, em 2006, de 74\%, enquanto o volume ofertado no MSP, de 37 mil UHs, assemelha-se ao de 2010 , no período do boom. A análise por triênio perscruta, ainda, os volumes médios da oferta e sua concentração na região, permitindo comparação entre três períodos: a) 2010-2012 (expansão/valorização): continuidade da elevação da oferta na RMSP iniciada no período do boom (2007-2009), com média anual de 64 mil UHs, sendo 54\% localizadas no MSP;

b) 2013-2015 (desaceleração): início da desaceleração da oferta na região, com média anual declinante, de 49 mil UHs, e concentração crescente no MSP, de $60 \%$;

c) 2016-2018 (retração): intensificação da redução da oferta na região, com média anual ainda menor, de 41 mil UHs, e início da recuperação da oferta no MSP (2017 e 2018), que concentra um volume ainda maior de unidades lançadas, de $71 \%$. 


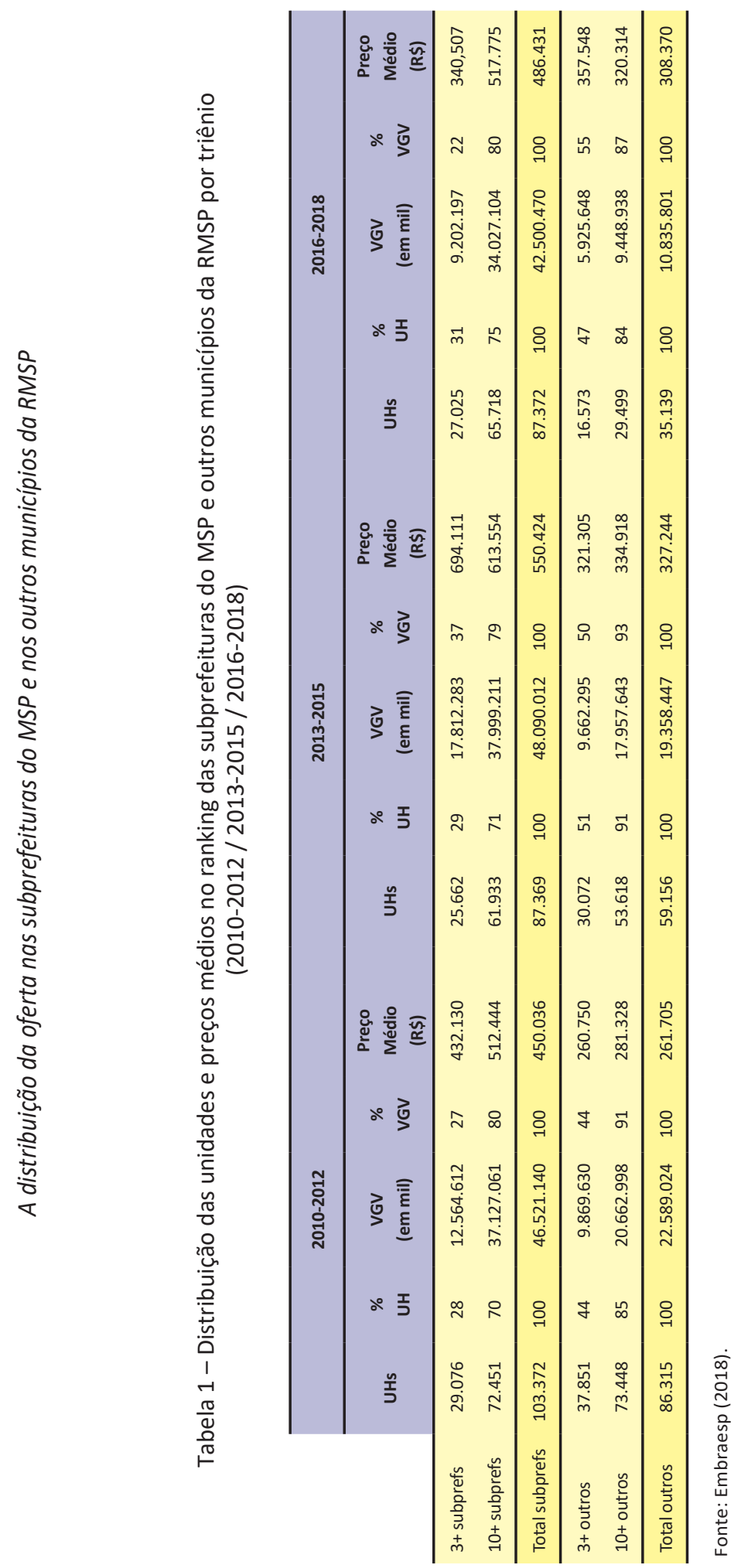




\section{Nas subprefeituras do MSP}

Ao analisar a localização da oferta de novas unidades, considerando os limites administrativos das subprefeituras da Capital, verifica-se, como já observado em períodos anteriores (Silva, 2015), a participação expressiva dos mercados tradicionalmente voltados aos estratos de médio-alto e alto padrão. Na comparação entre o período de expansão (2010-2012) e de retração (2016-2018), observa-se maior concentração da oferta nas dez primeiras subprefeituras do ranking, ${ }^{4}$ que se eleva de $70 \%$ a $75 \%$, enquanto elas mantêm sua participação no total do Valor Geral de Vendas (VGV) de $80 \%$. Na retração, verifica-se que subprefeituras periféricas passam a ocupar posição destacável no ranking, o que não ocorre no período da expansão, apesar do aumento da oferta nessas regiões se comparada à do pré-boom dos anos 2000. Isto revela uma alteração importante na distribuição territorial dos lançamentos na Capital, tendo as subprefeituras de Pirituba, na zona Norte; e Itaquera e Penha, na zona Leste, figurando entre as primeiras posições, com a oferta direcionada ao segmento econômico. Destaca-se, ainda, que algumas subprefeituras desse ranking da retração, já presentes nos períodos anteriores, garantem a sua permanência condicionada à diversificação da oferta, incorporando em determinadas parcelas de seus territórios produtos econômicos, como as subprefeituras de Butantã, na zona Oeste; Campo Limpo, na zona Sul; Mooca, na zona Leste; e Sé, na zona central.

Enquanto as três primeiras subprefeituras nos rankings da expansão, desaceleração e retração respondem por $30 \%$ das unidades lançadas na Capital, há uma variação significativa de suas participações nos totais do VGV. Em 2013-2015, essa participação alcança 37\%, com as subprefeituras Sé, Lapa e Pinheiros nessas posições; e, em 2016-2018, ela cai para 22\%, com a permanência da Sé, ascensão de Pirituba e retorno da Mooca nessa posição de destaque, evidenciando uma concentração de produtos econômicos na oferta.

Na retração, as 10+ subprefeituras perfazem um preço médio nominal da UH de R\$518 mil, enquanto a média na Capital é de $\mathrm{R} \$ 486$ mil. Considerando apenas as três primeiras, a média cai para $\mathrm{R} \$ 340$ mil, com uma concentração da oferta nos patamares de preço dos produtos econômicos.

\section{Nos outros municípios da RMSP}

A análise da distribuição territorial da oferta residencial na RMSP, excetuando a Capital, nos triênios de expansão/valorização (2010-2012), desaceleração (2013-2015) e retração (20162018), revela a presença de mercados muito fortes que concentram grande parte dos lançamentos na região, enquanto outros municípios se apresentam alijados diretamente da atuação dos agentes promotores do mercado formal. Em todos os períodos, a concentração da oferta nos 10 principais municípios ${ }^{5}$ foi superior a $84 \%$, oscilando pouco entre os ciclos de expansão (com oferta total de 86 mil UHs entre 2010 e 2012) e de retração (com oferta total reduzida de 35 mil UHs entre 2016 e 2018). Essa distribuição concentrada nas 10 primeiras localidades $(10+)$ é mais intensa que a verificada nas 10 principais subprefeituras da Capital (que variou entre $70 \%$, com oferta total de 103 mil UHs, e 75\%, com 87 mil UHs). Essa distinção entre os níveis de concentração da oferta se intensifica ainda mais se observados os três primeiros colocados, variando entre $44 \%$ e $50 \%$, enquanto na Capital é de $30 \%$ nos dois períodos. Já a concentração do VGV nos 
10+ municípios atinge patamares ainda maiores que a das $10+$ subprefeituras na Capital, alcançando 93\% na desaceleração (2013-2015). Essa concentração é crescente considerando os três primeiros municípios do ranking ao longo dos triênios analisados, atingindo 55\% na retração (2016-2018), com a participação destacada, nesse conjunto, de Barueri, município que concentra oferta voltada à demanda de mais alta renda. Observa-se, nos municípios fora da Capital, uma oferta de produtos cujos preços médios permanecem com pouca variação nos triênios de desaceleração e retração, mantendo-se em patamares do segmento econômico, de forma semelhante ao período de expansão. Mesmo com a expressiva participação dos recursos originários do SBPE, não se verifica a presença de montantes significativos de produtos mais caros, com exceção da oferta presente em algumas localidades, como Barueri, São Caetano e Santo André. Já, em municípios como São Bernardo e Osasco, ocorre oscilações nos preços médios, revelando maior diversificação dos produtos ofertados em decorrência de se constituírem como mercados maiores, atendendo a estratos de renda também diversificados, diferentemente de GuaruIhos, cuja oferta tem se posicionado entre os $3+$ municípios e apresenta preços médios sempre em patamares econômicos.

Dos 10 principais municípios no conjunto da oferta na retração, oito apresentam preços médios nominais nos níveis do segmento econômico, sendo seis deles com sua oferta majoritariamente enquadrada nos tetos das faixas de mercado do PMCMV.

Ao longo de todo o período analisado, sete municípios (Guarulhos, Osasco, São Bernardo, Santo André, Barueri, Cotia e Diadema) permanecem nas 10 primeiras posições do ranking e constituem-se em subtipos de mercado tradicionalmente consolidados da região ou se integram a vetores de expansão articulados aos primeiros, que alteram suas posições no ranking ao longo dos triênios analisados, em função das repercussões da crise.

\section{Especificidades do território metropolitano: as dinâmicas vetoriais e os subtipos de mercados na retração da oferta residencial na RMSP}

O mercado residencial formal brasileiro espeIha a concentração das rendas e das riquezas, bem como a desigualdade no acesso às terras urbanizadas e às propriedades ou posses de bens imobiliários, mormente para moradia. Por se apoiar na lógica de provisão da casa própria, estrutura-se, em grande medida, pautado pelos estratos de maior renda, uma vez que os demais têm sua solvabilidade fortemente dependente de políticas públicas, fontes de financiamento e subsídios de longo prazo. Historicamente, o mercado residencial formal é restrito e consolida-se de forma concentrada no território, conformando uma produção, como descrita por Maricato (1984) e Vargas (1983), nos anos 1980, de "artesanato de luxo". Nos períodos de ampliação de suas fronteiras, há a inserção de novas localidades em decorrência de condições macroeconômicas favoráveis, com o aumento do rendimento e da capacidade de poupança da população, como ocorre na segunda metade dos anos 1990 na RMSP, e também de políticas de ampliação do financiamento, com oferta de 
descontos e subsídios, como na segunda metade dos anos 2000 (Castro, 1999; Sígolo, 2014). Porém, essas novas fronteiras do mercado formal demonstram fragilidades na permanência dessa inserção nos circuitos imobiliários mais dinâmicos, apresentando oscilações no volume da oferta, a depender de sua localização e de sua articulação com vetores de expansão e subtipos de mercado consolidados, em razão de mudanças nos ciclos econômicos com repercussões no setor imobiliário.

\section{As dinâmicas vetoriais da oferta residencial na RMSP}

A formação dos vetores de expansão da oferta residencial responde aos condicionantes da ampliação da escala produtiva, do espraiamento geográfico e da formação de valor e obtenção de rendas na incorporação imobiliária.

Na RMSP, durante o período expansivo, observa-se o avanço das fronteiras do mercado formal de moradia em direção às periferias metropolitanas, atravessando, pelas lógicas e estratégias definidas pelos agentes promotores, limites político-administrativos municipais. Em grande medida, esses vetores de expansão da oferta são capitaneados por produtos do segmento econômico, em resposta à ampliação da oferta de financiamentos pelos fundos público e semipúblico voltados para esses estratos, revigorando o mercado metropolitano, para além da Capital.

Os vetores de expansão da oferta aqui analisados, que englobam diferentes municípios da região por meio da dinamização de mercados contíguos e mediante a tomada de decisões pelos agentes envolvidos na cadeia da provisão com unidade circunstancial, apresentam-se sem uma articulação fundamentada em diretrizes ou estratégias de desenvolvimento regional ou metropolitano, segundo organismos com competência de planejamento e gestão abrangentes para estabelecer políticas de coesão e integração urbana em consonância às práticas do mercado imobiliário.

A análise das dinâmicas vetoriais da oferta residencial na RMSP é elaborada a partir da localização e distribuição dos lançamentos residenciais cotejadas com os dados dos rankings da oferta dos municípios da região e das subprefeituras do MSP, considerando os três triênios analisados: de expansão/valorização (2010-2012), de desaceleração (20132015) e de retração (2016-2018).

Este estudo contribui na identificação de permanências e alterações nessas dinâmicas, que refletem as estratégias locacionais e mercadológicas adotadas pelas empresas promotoras em períodos de mudanças macroeconômicas e setoriais, que envolvem, inclusive, diferentes níveis de entrelaçamento com as finanças (da disponibilização de recursos financeiros à sua efetiva mobilização) nos triênios de desaceleração e de retração, com repercussões na distribuição da oferta de unidades na Capital e nos demais municípios da metrópole paulistana.

Destarte, essas dinâmicas também são observadas com base nos principais elementos estruturadores dos vetores de expansão da oferta na região, como o sistema de mobilidade urbana (metroferroviário) e eixos viários, que cruzam o território metropolitano e the orientam, além de grandes equipamentos urbanos de influência regional. 
Mapa 1 - Distribuição dos lançamentos residenciais na RMSP

(2010-2012 e 2016-2018)
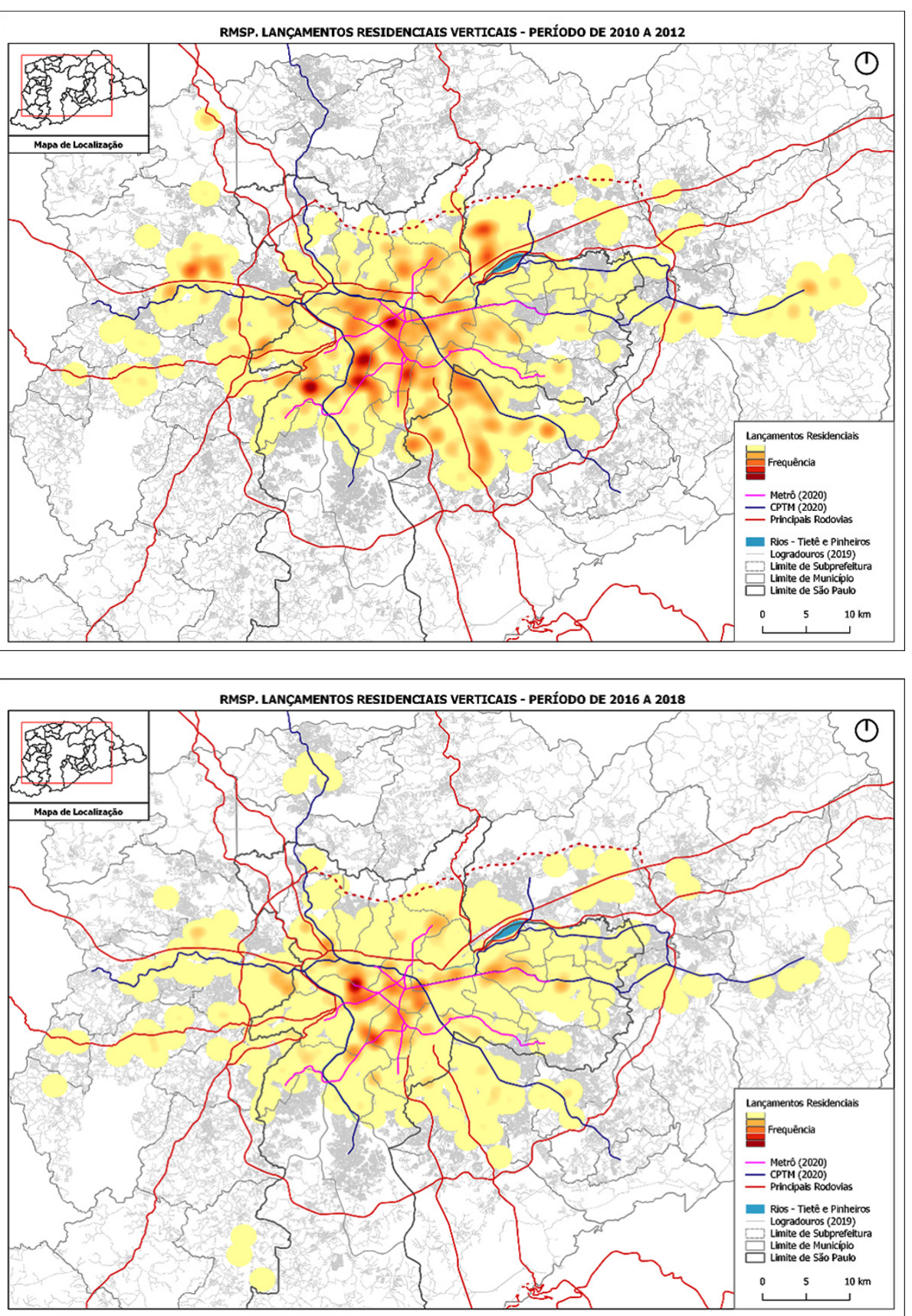

Fonte: Embraesp (2018). Elaborado por Gabriel Marques. 
Desse modo, foram identificados seis vetores de expansão que conduzem a análise do comportamento da oferta residencial na RMSP posicionados a leste, a sudeste, a sudoeste, a oeste, a nordeste, além da área central do MSP.

$O$ vetor leste abrange os municípios da sub-região leste da RMSP e as subprefeituras da zona leste e extremo leste do MSP, acompanhando as linhas férreas da CPTM 11 - Coral, que se estende até Mogi das Cruzes, e da CPTM 12 - Safira, que se estende até Poá, e é alimentado por eixos viários que cruzam a região no sentido leste-oeste, como as avenidas São Miguel e Marechal Tito, mais à norte; as avenidas Aricanduva e Conselheiro Carrão, mais ao centro; e as avenidas Regente Feijó/ Abel Ferreira, em conexão direta com a subprefeitura da Mooca, pelo distrito do Tatuapé. Considerando o comportamento da oferta no triênio de expansão/valorização da oferta na RMSP e nos anos de desaceleração e de retração, observa-se um encolhimento desse vetor, quando os lançamentos se restringem majoritariamente à Capital. Destaca-se que a redução da oferta no último triênio analisado atinge, ainda, os distritos mais periféricos a leste do MSP, mantendo-se uma importante oferta em ascensão nas subprefeituras da Mooca, da Penha e de Itaquera, no anel intermediário da cidade. Nesse período, o vetor leste manteve sua participação no total do número de unidades lançadas semelhante à do período de expansão, em torno de $20 \%$, acompanhando a redução em números absolutos verificada no conjunto dos lançamentos da cidade. Os municípios externos a leste, como Mogi das Cruzes e Suzano, são severamente atingidos na desaceleração e na retração da oferta na RMSP. Relativamente, o primeiro foi mais atingido, tendo a sua participação no total de unidades lançadas na RMSP, exceto a Capital, reduzida de $8 \%$ em $2010-2012$ a 0,5\% em 2016-2018.

0 vetor nordeste abrange o município de Guarulhos e as subprefeituras de Vila Maria/ Vila Guilherme, Santana/Tucuruvi e Tremembé/Jaçanã na zona norte da Capital e é estruturado pelas rodovias Dutra e Fernão Dias e pela linha 1 do Metrô - Azul. Na análise do comportamento da oferta nos períodos de expansão/valorização e de retração, observa-se um encolhimento desse vetor quando Guarulhos, que teve grande participação no conjunto da oferta na RMSP, exceto a Capital, no período de expansão, perde dinamismo (de 22\% para 16\% e de 19.200 UHs para 5.600 UHs). Concomitantemente, ainda que se verifique o prolongamento do vetor internamente ao MSP, os lançamentos nos distritos de Jaçanã, Vila Medeiros, Tucuruvi e Mandaqui, mais a norte nas subprefeituras da Capital, não compensam essa redução.

A sub-região oeste da RMSP apresenta dois vetores de expansão que acompanham dois eixos viários, as rodovias Castelo Branco e Raposo Tavares e a linha férrea da CPTM 8 Diamante, todos de influência regional.

0 vetor oeste 1 parte da subprefeitura da Lapa em direção a Osasco e Barueri, direcionado pela rodovia Castelo Branco e pela linha férrea. Na análise dos períodos de expansão/ valorização (2010-2012) e de retração (20162018), observa-se um encolhimento desse vetor externamente à Capital em direção a Osasco, que apresenta crescimento de volume e de sua participação no conjunto dos lançamentos da RMSP, exceto o MSP, de $5.500 \mathrm{UHs}$ e $6 \%$, para 7.200 UHs e $20 \%$. Barueri, apesar de manter uma importância significativa nesse vetor, com participação de $11 \%$ nos dois períodos, 
não acompanha esse aquecimento de Osasco, tendo o volume da oferta reduzido de 9.600 UHs para 3.800 UHs. Ao mesmo tempo, a subprefeitura da Lapa apresenta pequenas oscilações no volume e em sua participação no total das unidades lançadas na Capital, de 7600 UHs e $7 \%$, para 5.550 UHs e $6 \%$. O vetor oeste 2 parte da subprefeitura do Butantã e estende-se até Cotia, direcionado pela rodovia Raposo Tavares, também cruzando o município de Osasco ao sul. Cotia apresenta uma oferta estável, de cerca de 3.500 UHs, nos dois períodos, e, assim, alcança uma participação importante no conjunto dos lançamentos da RMSP fora da Capital na retração, de 4\% passa para $10 \%$. Já a subprefeitura do Butantã apresenta crescimento no volume e em sua participação no conjunto dos lançamentos da Capital, de 4.800 UHs e $5 \%$, para 7.000 UHs e $8 \%$, em grande medida, apoiado na oferta de produtos do segmento econômico e na ampliação da linha 4 do Metrô - Amarela. Esse vetor é o único que não revela encolhimento na retração.

Apesar do dinamismo apresentado pelo vetor oeste 2 na retração, o vetor oeste 1 revela-se mais importante nesse reposicionamento do mercado imobiliário residencial na RMSP, com o protagonismo de municípios fora da Capital, destacadamente Osasco e Barueri, sendo o primeiro o único município fora da Capital que apresenta crescimento no volume de unidades lançadas.

$O$ vetor sudoeste abrange apenas um município da sub-região sudoeste, Taboão da Serra. Na análise dos períodos de expansão/valorização e de retração, observa-se sua importância atrelada à rodovia Régis Bittencourt que atravessa o município de Taboão, constituindo-se em um transbordamento do mercado da subprefeitura do Campo Limpo, com a ampliação da fronteira ocorrida durante o período expansivo. Na retração, há encolhimento do vetor externamente à Capital, e a subprefeitura do Campo Limpo mantém dinamismo relevante no conjunto da oferta do MSP, mesmo apresentando redução de volume (de $9.200 \mathrm{UHs}$ para $5.500 \mathrm{UHs}$ ) e de sua participação (de $9 \%$ para $6 \%$ ) em relação à expansão.

0 vetor sudeste abrange os municípios da sub-região do $A B C D$ e as subprefeituras de Ipiranga e Vila Prudente/Sapopemba. $\mathrm{Na}$ análise dos períodos de expansão e de retração da oferta na RMSP, observa-se a redução no volume de unidades lançadas nesse vetor. Sua permanência no segmento externo à Capital é acompanhada pelo estreitamento da sua borda a oeste, compreendendo parte do município de São Bernardo, com concentração de lançamentos a leste entre a linha férrea da CPTM 10 - Turquesa e a rodovia Anchieta, nos municípios de Santo André e São Bernardo. Além disso, outra importante redução ocorre no município de São Caetano. No MSP, o vetor mantém o mesmo percentual ( $9 \%$ ) de participação nos lançamentos do período da expansão (2010-2012) no da desaceleração (20132015), mas na retração (2016-2018), este se reduz (7\%). Destaca-se que as duas subprefeituras concentram a maior oferta do vetor (6.400 UHs), enquanto São Bernardo e Santo André respondem por um volume muito menor, de apenas $3.700 \mathrm{UHs}$. Isto contrasta com a importante oferta de São Bernardo (9 mil UHs) na expansão que equivalia a dessas duas subprefeituras neste mesmo período.

A área central, após mais de duas décadas (1980 e 1990) de perda populacional e consequente concentração de vacância imobiliária, ganha maior importância no período 
de expansão/valorização e potencializa-se no período de retração, quando a subprefeitura da Sé assume a primeira posição no ranking de lançamentos na Capital, apresentando um crescimento de volume (de 9.200 UHs para 11.000 UHs) e de sua participação (de $9 \%$ para $13 \%)$. Esse mercado abrange os distritos mais a oeste do centro, como Barra Funda, Santa Cecília, Bom Retiro e Consolação, e mais a sudoeste/sul como: Bela Vista, Liberdade e Cambuci, e constitui-se a partir da ampliação dos vetores oeste, sudoeste e sudeste, compreendendo o centro expandido com mercados já bastante consolidados da Capital, como Lapa, Perdizes, Pinheiros, Jardim Paulista, Vila Mariana e Ipiranga. Parte dessa "redescoberta" do centro está associada a uma estratégia de diversificação de portfólio das empresas, apoiada majoritariamente na constituição de um nicho específico de mercado no segmento econômico, além da expansão do mercado de médio e alto padrão em direção à área central da Capital.

A norte e a sul da RMSP, vetores não são identificados segundo eixos de expansão abrangendo municípios fora da Capital. Cumpre observar a presença de áreas ambientalmente frágeis cuja ocupação é legalmente restringida nessas regiões, abrangendo vários municípios. Na região sul, encontram-se algumas das subprefeituras com os mercados mais maduros, destacadamente Santo Amaro e Vila Mariana, que se posicionam entre as 10 mais dinâmicas da Capital na expansão. No entanto, somente a Vila Mariana apresenta crescimento no volume e em sua participação nos lançamentos da Capital na retração, de 5.600 UHs e $5 \%$ para 6.300 UHs e $7 \%$, permanecendo bem-posicionada no ranking da oferta do MSP; enquanto Santo Amaro apresenta queda importante, de 6.500 UHs e $6 \%$ para 2.800 UHs e $3 \%$. No extremo sul, as subprefeituras que apresentam lançamentos na expansão seguem a trajetória dos subtipos de mercado frágeis, reduzindo ainda mais a sua participação no conjunto da oferta na retração.

A norte na Capital, a oferta nas subprefeituras de Casa Verde/Cachoeirinha, Freguesia do Ó/Brasilândia, Perus e Pirituba alcançou um dinamismo restrito na expansão e queda na retração, com exceção de Pirituba, que passa de 1.000 UHs (1\%) para 8.500 UHs (10\%), e assume a segunda posição no ranking de lançamentos na Capital. Considera-se que esse desempenho é impulsionado pela presença da linha férrea da CPTM 7 - Rubi e previsão de transposição do rio Tietê no eixo da avenida Raimundo Pereira de Magalhães, além das rodovias Anhanguera/Bandeirantes, que se constituem em eixos de conexão entre a RMSP e a Região Metropolitana de Campinas (RMC), de grande importância econômica regional no contexto da reestruturação produtiva e territorial.

\section{Os subtipos de mercado na RMSP}

A Região Metropolitana de São Paulo é o centro do sistema financeiro-imobiliário nacional e é composta por distintos tipos de mercado, dentre eles, o residencial. 0 mercado residencial, por sua vez, é analisado a partir dos diferentes subtipos de mercado, que se constituem no interior dessa região. Nesses subtipos de mercado, as dinâmicas desenvolvem-se por meio de articulações, complementaridades e interdependências em diversas escalas. Tanto as formas como os processos desse conjunto têm o Estado como facilitador e gestor de uma moldura institucional essencial para o seu 
desenvolvimento, seja financiando a produção, solvabilizando a demanda, promovendo as infraestruturas urbanas ou estabelecendo um marco legal para o desenvolvimento urbano.

Em uma metrópole como São Paulo, os subtipos de mercado estão em constante redefinição, podendo se deslocar, ampliar ou encolher, conferindo uma alteração de hierarquia entre eles, incluindo níveis distintos de consolidação e de fragilidade a depender dos ciclos econômicos e dinâmicas do setor da construção, incluso o imobiliário.

Esse mercado se desenvolve de forma contínua e cumulativa do ponto de vista da produção social do espaço, por meio de investimentos públicos e privados, individuais e coletivos, por décadas, até atingir sua maturidade, constituindo-se subtipos de mercado consolidados.

No período analisado, essa consolidação, em território metropolitano, deve-se, em grande medida, à sua inserção em um vetor de expansão da oferta, que, geralmente, acompanha eixos viários e/ou redes de transporte de média e alta capacidade e se fortalece pela proximidade de grandes equipamentos de infraestrutura (aeroportos, portos secos, etc.), distritos ou condomínios industriais e de serviços, grandes centros de distribuição/logística e de consumo (hipermercados, shoppings, e-commerces, complexos esportivos, educacionais, recreativos, grandes centros de exposições e convenções, etc.), que geram novas centralidades, com maior complexidade e multiescalaridade.

Alguns subtipos de mercado atingem patamares elevados de oferta em períodos curtos, decorrentes de convergências de fatores impulsionadores, ancorados por grandes infraestruturas e/ou projetos urbanos e pela existência de vantagens locacionais e oportunidades fundiárias para novos negócios, entre outros. Constituem-se subtipos de mercado emergentes, com desempenhos mais suscetíveis às crises, portanto, apresentam mercados frágeis, quando respondem com crescimento incipiente e maior exposição à volatilidade da oferta (volume e preço). Mesmo os consolidados, sofrem com os períodos de retração, mas, apesar da queda na oferta, mantêm volumes de lançamento expressivos, conservando a sua importância no sistema financeiro-imobiliário da região.

O mercado residencial, quando dinamizado por um movimento de massificação e ampliação de volume de unidades novas, dá corpo a lógicas sistêmicas de precificação (produtiva, mercantil e financeirizada) que se sobrepõem às preexistentes. Essa precificação é seguida por uma valorização fundamentada por expectativas de crescimento de preços parametrizadas, inclusive, por atributos de diferentes subtipos de mercado, como os dos consolidados e, eventualmente, os dos emergentes, que apresentam elevado dinamismo e capacidade potencial de alavancagem de preços, marcantes no território da metrópole.

Observa-se que, no período de expansão e valorização da oferta residencial na RMSP, também ocorre uma tendência de homogeneização da oferta, apoiando-se em estratégias locacionais, produtivas e mercadológicas das empresas promotoras com vistas a maximizar seus ganhos, ajustando-se aos critérios de enquadramento nos financiamentos disponíveis, direcionados, principalmente, ao segmento econômico.

Nesse contexto de intensa valorização imobiliária e insuficiência na regulação sobre o mercado de terras, essa tendência de homogeneização da oferta encontra a necessidade de 
redefinição de seu posicionamento no território, em decorrência da reestratificação dos preços imobiliários ascendentes. Assim, a oferta de produtos mais econômicos inviabiliza-se em territórios intermediários, segundo as métricas dos agentes promotores, que, por sua vez, direciona-a para novas fronteiras urbanas, inclusive em outros municípios. Essas novas localidades podem compor vetores de expansão e subtipos de mercado frágeis, emergentes ou não.

Já, no período de desaceleração e retração dessa oferta na RMSP, o mercado segue apresentando a mesma tendência de homogeneização da oferta e mantém a aposta na generalização de modelos de produtos econômicos adequados aos condicionantes de viabilidade físico-financeira e mercadológica. No entanto, há que considerar que a oferta, embora contraída, permanece nos vetores do boom, preponderantemente nos subtipos de mercado consolidados, mas também nos frágeis emergentes, cuja oferta ocorre mediante oportunidades pontuais apoiadas em grandes projetos de infraestrutura urbana e de implantação de novos bairros em grandes glebas vazias. Nesse mesmo período, a oferta do segmento econômico revela uma outra tendência no mercado, que é a de diversificação de produtos caracterizada pela intensificação no uso do solo urbano, com altas densidades construtivas, habitacional e populacional nos empreendimentos ofertados de forma concentrada em fragmentos do território. Constitui-se, assim, um nicho desse segmento na área central do MSP, que se comporta como subtipo de mercado consolidado e reúne uma gama diversificada de produtos.

\section{Subtipos de mercado consolidados}

Elabora-se, a seguir, uma categorização dos subtipos de mercado, tendo em vista o volume da oferta anual de unidades e suas variações ao longo do período analisado, assumindo os limites administrativos municipais e, na Capital, a delimitação territorial das subprefeituras. Assim, são considerados como subtipo de mercado consolidado A, os municípios e as subprefeituras que têm oferta igual ou superior a $2.000 \mathrm{UHs} /$ ano em ao menos um dos períodos analisados (2010-2012, 2013-2015 e 20162018) e nunca médias inferiores a 1.000 UHs/ ano. São eles: Guarulhos, Osasco, Barueri, São Bernardo e Santo André. E, no MSP, as subprefeituras: Sé, Mooca, Pinheiros, Campo Limpo, Lapa, Vila Mariana e Santo Amaro.

O único município classificado como subtipo de mercado consolidado $B$, pois apresenta oferta entre 1.000 e $2.000 \mathrm{UHs} / \mathrm{ano}$, nos três períodos analisados, é Cotia, constituinte do vetor oeste estruturado pela rodovia Raposo Tavares, que não sofre encolhimento na retração. Na capital, as subprefeituras Butantã, Ipiranga e Vila Prudente/Sapopemba, parte de vetores oeste e sudeste, respectivamente, também se enquadram nesse grupo. São Caetano e Diadema, apresentando, no período de expansão, oferta entre 1.000 e $2.000 \mathrm{UHs} /$ ano e na retração entre 1000 e 450 UHs/ano, são classificados como subtipo de mercado consolidado C, assim como as subprefeituras Santana/Tucuruvi, Penha e Aricanduva.

Mesmo apresentando uma participação relevante no conjunto da oferta fora do MSP na RMSP, os municípios classificados como 


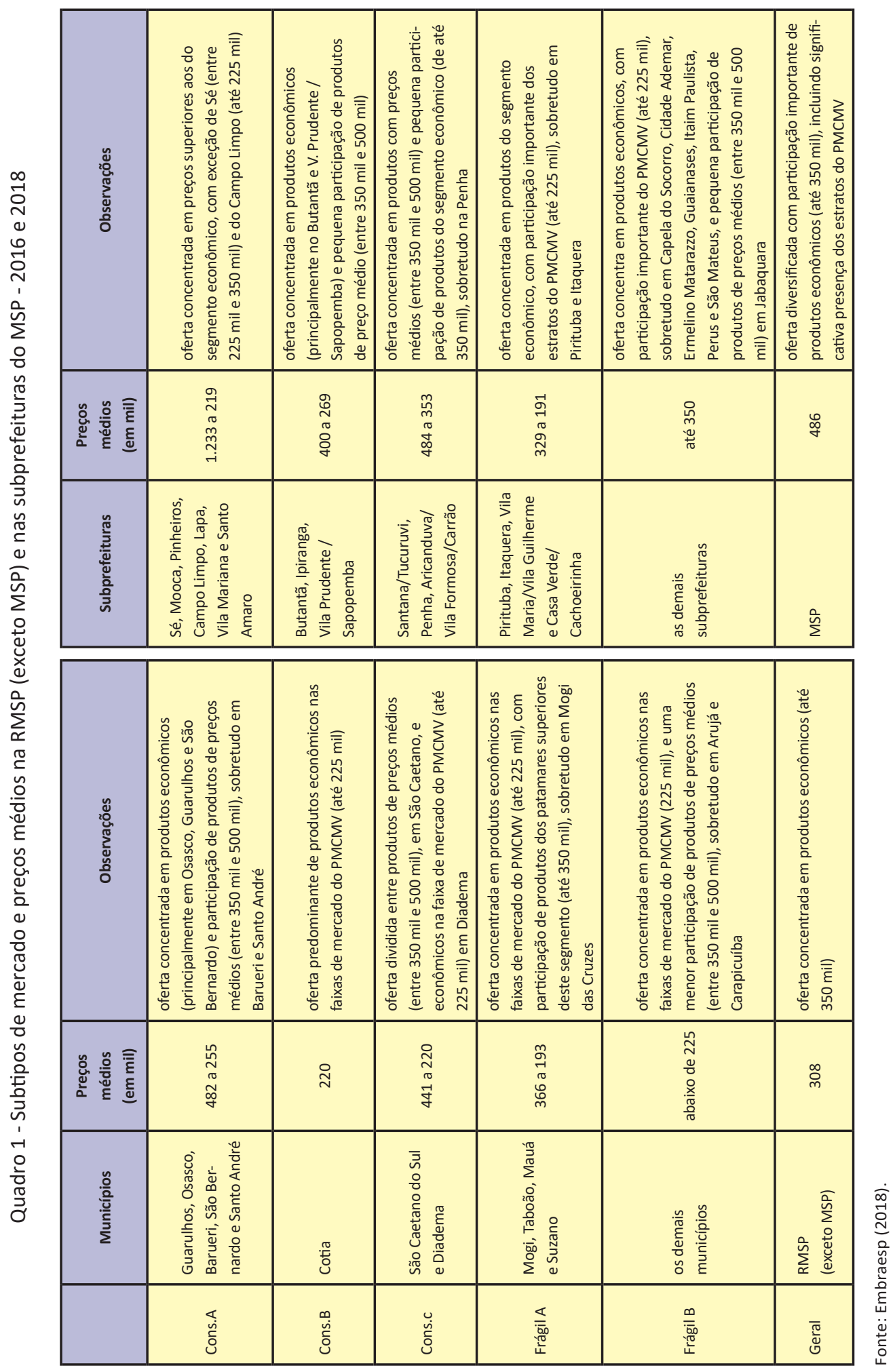


subtipos de mercado consolidados, em sua quase totalidade, têm redução no volume de sua oferta nos dois últimos triênios enquanto os lançamentos se concentram nos subtipos de mercado consolidados internos à Capital.

\section{Subtipos de mercado frágeis}

Alguns municípios da RMSP e subprefeituras do MSP, antes com participação incipiente no conjunto dos lançamentos na região, passam a ofertar um volume significativo de unidades no período de expansão (2010-2012), em torno de $1.000 \mathrm{UHs} / a n o$, com base em produtos econômicos. Na retração (2016-2018), essas localidades revelam sua incapacidade de sustentar médias de lançamentos superiores a $450 \mathrm{UHs} /$ ano, pelo encolhimento do conjunto dos vetores de expansão da oferta na RMSP, dada a dependência que estabelecem com a política de financiamento acompanhada pela queda no rendimento das famílias. Outras localidades sequer apresentam volume de oferta significativo no boom. E todos eles enquadram-se como subtipos de mercado frágeis.

Os municípios Mogi das Cruzes, Taboão da Serra, Mauá e Suzano, ainda que apresentem uma oferta com alguma expressividade na expansão e façam parte de vetores (leste, sudoeste, sudeste e leste, respectivamente), devido às oscilações no comportamento de sua oferta no período analisado e ao fato de parte importante deles ter sido fortemente impactada pela retração, são classificados como subtipo de mercado frágil A. Na Capital, as subprefeituras Vila Maria/Vila Guilherme e Casa Verde/Cachoeirinha também enquadram-se nesse grupo, com oferta anual entre $450 \mathrm{UHs}$ e 1.000 UHs. Já as subprefeituras de Pirituba e Itaquera, situadas nesse mesmo grupo, mostram um desempenho relevante nos períodos de desaceleração e de retração, com média superior a $1.000 \mathrm{UHs} / a n o$, destacadas, assim, como subtipos de mercado emergentes.

Os demais municípios da RMSP apresentam oferta inferior a $450 \mathrm{UHs/ano} \mathrm{ao} \mathrm{longo}$ dos dois períodos analisados e são enquadrados como subtipo de mercado frágil B. Além destes, há um grupo significativo de subprefeituras do MSP que fazem parte desse mesmo subtipo.

\section{Características gerais da oferta residencial na RMSP no período da retração}

A análise do comportamento da oferta na RMSP no período da retração é complementada pela verificação de alterações nas características gerais dos produtos e em seus preços médios e áreas úteis e totais, bem como nas participações das incorporadoras.

\section{Características gerais \\ dos produtos lançados}

No período analisado (2010-2018), há evidências de redução progressiva nas dimensões médias (área total - AT e área útil - AU) das unidades lançadas. Na retração, essa tendência é mais intensa no MSP, com variação de $24 \%$ na AT e $22,5 \%$ na AU, quando comparada à de 2010-2012, de $135 \mathrm{~m}^{2}$ passa para $103 \mathrm{~m}^{2}$ e de $73 \mathrm{~m}^{2}$ para $56 \mathrm{~m}^{2}$. Nos demais municípios, essas médias apresentam uma redução menor, de $13 \%$ e $15 \%$, respectivamente, de 125 $\mathrm{m}^{2}$ para $108 \mathrm{~m}^{2}$ e de $68 \mathrm{~m}^{2}$ para $58 \mathrm{~m}^{2}$. Essas reduções nas áreas das unidades lançadas não 
Tabela 2 - Síntese das características gerais da oferta residencial na RMSP, MSP e outros municípios

\begin{tabular}{l|c|c|c|c|c|c|c|c|c}
\hline \multirow{2}{*}{ Síntese das informações } & \multicolumn{3}{|c|}{ RMSP } & \multicolumn{3}{c|}{ MSP } & \multicolumn{3}{c}{ Outros municípios } \\
\cline { 2 - 11 } & $\mathbf{2 0 1 0 /}$ & $\mathbf{2 0 1 3 /}$ & $\mathbf{2 0 1 6 /}$ & $\mathbf{2 0 1 0 /}$ & $\mathbf{2 0 1 3 /}$ & $\mathbf{2 0 1 6 /}$ & $\mathbf{2 0 1 0 /}$ & $\mathbf{2 0 1 3 /}$ & $\mathbf{2 0 1 6 /}$ \\
$\mathbf{2 0 1 2}$ & $\mathbf{2 0 1 5}$ & $\mathbf{2 0 1 8}$ & $\mathbf{2 0 1 2}$ & $\mathbf{2 0 1 5}$ & $\mathbf{2 0 1 8}$ & $\mathbf{2 0 1 2}$ & $\mathbf{2 0 1 5}$ & $\mathbf{2 0 1 8}$ \\
\hline UHs / Empreend. & 130 & 99 & 131 & 104 & 76 & 118 & 184 & 185 & 182 \\
\% UHs Verticais & $97 \%$ & $95 \%$ & $97 \%$ & $97 \%$ & $95 \%$ & $98 \%$ & $96 \%$ & $95 \%$ & $96 \%$ \\
Consumo de terreno / UH & 36 & 31 & 29 & 31 & 29 & 24 & 41 & 35 & 41 \\
AT Média & 130 & 117 & 104 & 135 & 119 & 103 & 125 & 113 & 108 \\
AU Média & 70 & 63 & 57 & 73 & 64 & 56 & 68 & 65 & 58 \\
AU/AT & 0,54 & 0,54 & 0,54 & 0,54 & 0,54 & 0,55 & 0,54 & 0,58 & 0,53 \\
\hline
\end{tabular}

Fonte: Embraesp (2018).

alteram a relação entre a AU e a AT, mantendo-se, ao longo de todo o período, em torno de 0,54 . A redução acentuada verificada na Capital revela o reposicionamento da oferta na RMSP com o aumento da presença de produtos econômicos nesse município, o que já era recorrente nos demais da região.

Além disso, no MSP, essa redução dimensional é acompanhada pela diminuição do consumo médio de terreno por unidade, de $31 \mathrm{~m}^{2}$, em 2010-2012, para $24 \mathrm{~m}^{2}$, em 2016-2018, enquanto, nos demais municípios, essa relação pouco se altera, permanecendo em torno de $40 \mathrm{~m}^{2}$. Nestes últimos, observa-se, ao longo de todo o período, a presença de empreendimentos de grande porte com médias de unidades sempre superiores a 180 UHs, enquanto, na Capital, ainda que tenham se ampliado no último triênio analisado, elas não superam 118 UHs.

Tais mudanças conferem a oferta de unidades menores em toda a região, e, na Capital, de empreendimentos ainda mais adensados e mais verticalizados.

\section{Comportamento dos preços de lançamento}

A análise do comportamento dos preços da oferta residencial na RMSP, nos distintos períodos, dentro e fora da Capital, é realizada a partir dos preços médios nominais, que, na sequência são cotejados com os preços médios deflacionados pelo IGP-DI para dezembro de 2018. 0 estudo é complementado com a estratificação dos preços médios nominais, tendo, como referência para a definição dos estratos, os tetos dos financiamentos disponíveis no âmbito do Sistema Financeiro Habitacional (SFH-FGTS) e no do PMCMV. Assim os dados levantados revelam movimentos de reestratificação dos preços praticados na RMSP mediante crescimento, com rearranjos na distribuição da oferta, que a reescalonam nos diferentes estratos. A análise da reestratificação dos preços nominais evidencia as respostas da oferta às mudanças no financiamento e nos condicionantes macroeconômicos e socioespaciais. Desse modo, esta análise, acompanhada pela dos preços médios deflacionados, tem a potencialidade 
de compreender as estratégias de precificação e valorização adotadas pelos agentes promotores do setor e sua relação com a disponibilização dos recursos financeiros, mormente oriundos do FGTS e do Sistema Brasileiro de Poupança e Empréstimo (SBPE).

No período expansivo, observa-se um desencadeamento de elevada valorização imobiliária e fundiária, provocando mudanças nos patamares de preços das unidades novas; o desaparecimento da oferta com preços mais baixos, impulsionado pelas mudanças nos tetos do financiamento, sobretudo no âmbito do PMCMV; e a realização dos preços em patamares mais elevados nos territórios periféricos. Há, nesse período, a generalização da valorização imobiliária na RMSP, com maior intensidade nas novas fronteiras do mercado econômico, com variações internas, tendo, no MSP, os preços mais elevados.

Entre 2013 e 2014, há uma elevação na oferta de produtos com preços acima de $\mathrm{R} \$ 350$ mil na RMSP, quando se tem no país o auge do fluxo de crédito no SBPE (superior a R\$145 bi em 2013). Nestes anos, o MSP lança mais de 32 mil UHs/ano com preços médios nominais de $\mathrm{R} \$ 602 \mathrm{mil}$ (2013) e $\mathrm{R} \$ 558 \mathrm{mil}$ (2014). Em 2015 e 2016, na RMSP, há uma redistribuição da oferta nas faixas de preço seguida por um aumento na concentração da oferta nas inferiores a R\$350 mil nos anos seguintes. No MSP, nestes dois anos, verifica-se uma expressiva redução no volume dos lançamentos, de 35\%, acompanhada por um decréscimo nos preços médios das unidades, alcançando $\mathrm{R} \$ 458 \mathrm{mil}$ em 2015 e R\$525 mil em 2016.

No período de retração, observa-se, então, uma drástica redução de crédito no âmbito do SBPE, que totaliza R\$41 bi em 2018, ano em que a oferta nas faixas de preços inferiores a $\mathrm{R} \$ 350$ mil aumenta fortemente sua participação na região, concentrando $65 \%$ dos lançamentos na Capital e 70\% no conjunto da RMSP. Ou seja, a cada três unidades lançadas, pelo menos duas se enquadram no segmento econômico. Nos anos 2017 e 2018, observa-se um cenário de retração no mercado da região enquanto na Capital ocorre uma recuperação com oferta crescente, alcançando 31 mil UHs em 2017 e 37 mil UHs em 2018. Neste período, há redução nos preços médios nominais das unidades lançadas no MSP que atingem R\$461 mil em 2017 e R\$488 mil em 2018, revelando um reposicionamento deste mercado mediante a redução dos recursos para financiamento de produtos de maior preço com o crescimento da oferta no segmento econômico.

Este reposicionamento da oferta na RMSP, com o aumento da participação dos produtos do segmento econômico, sobretudo no MSP, na retração, também é verificado utilizando-se da análise do comportamento dos preços deflacionados pelo IGP-DI para dezembro de 2018. Entre 2013 e 2018, o preço médio das unidades deflacionado, na RMSP, sofre queda importante, de $25 \%$ (R\$638 mil para $\mathrm{R} \$ 478$ mil), enquanto, no MSP, ela é ainda maior, de 34\% ( $R \$ 796$ mil para $R \$ 523$ mil), já nos outros municípios, ela é moderada, de 16\% ( $\mathrm{R} \$ 411$ mil para $\mathrm{R} \$ 345$ mil). Todavia, não se verifica a mesma intensidade de redução com relação ao preço médio do $\mathrm{m}^{2}$ da $\mathrm{AU}$ deflacionado, de $12 \%$ (de $\mathrm{R} \$ 9.600$ para $\mathrm{R} \$ 8.400$ ), na RMSP; de 17\% (de R\$11.300 para R\$9.400), no MSP; e de $15 \%$ (de $R \$ 6.700$ para $R \$ 5.700$ ), nos outros municípios da região.

Essas mudanças mostram que no MSP, os agentes imobiliários adotaram estratégias para garantir a viabilidade do negócio no contexto de redução de financiamento de 
produtos mais caros, utilizando-se de adequações nas características dos empreendimentos e com isso minimizando o impacto da queda do preço médio das unidades no preço médio do $\mathrm{m}^{2}$ da AU. Nos outros municípios da RMSP, estas estratégias não são adotadas, uma vez que o reposicionamento da oferta para eles significa apenas a redução de seu volume sem modificações expressivas nas características dos empreendimentos, mantendo a predominância de produtos do segmento econômico.

Conforme observado anteriormente, na retração, há um encolhimento dos vetores de expansão da oferta na RMSP, que, em grande medida, passam a se restringir à Capital, reposicionando a oferta segundo a disponibilidade de financiamento, que, a partir de 2015, apoiou-se fortemente nos recursos oriundos do FGTS no âmbito do PMCMV. A presença do segmento econômico no MSP nos anos 2017 e 2018 é a confirmação dessa dinâmica. Nesse período, além da Capital passar a concentrar $71 \%$ das unidades lançadas, os outros municípios da RMSP vão ao encontro dessa tendência, apesar da redução significativa no volume de seus lançamentos.

Em face da estreita relação entre o comportamento dos preços e os valores unitários máximos dos financiamentos disponíveis, é elaborada uma estratificação de preços nominais das unidades lançadas com base nos tetos dos financiamentos, anualmente, permitindo uma comparação entre os períodos estudados. Nesta análise, é considerada a localização da oferta em três dimensões territoriais, na RMSP como um todo, na Capital e nos outros municípios da região.

Destaca-se, ainda, que os anos 2015 e 2016 são marcados pela desvalorização do real (R\$) em relação ao dólar (US\$), perdurando até os dias atuais, e que, nesses anos, são atingidas as maiores taxas básicas de juros (Selic), apresentando, em seguida, redução progressiva.

Assim, observam-se alguns movimentos de maior relevância para a análise das alterações e continuidades no comportamento do preço da oferta na retração:

a) a oferta de produtos com preços nas faixas de mercado (2 e 3) do PMCMV, ainda que presente em 2010-2012, apresenta tendência de queda progressiva até 2014. Em outubro de 2015, há uma elevação nos tetos do Programa, de $\mathrm{R} \$ 190$ mil para $\mathrm{R} \$ 225$ mil nas faixas 2 e 3 , e isto permite a captação de uma parte da oferta que antes se situava acima do preço máximo de enquadramento no Programa até então vigente e, ainda, garante, ao setor, uma alavancagem pela canalização de mais recursos oriundos do FGTS. A partir de 2015, há uma retomada da oferta nessas faixas de preço em toda a região, e, em 2017 e 2018, esses produtos ganham ainda mais volume e participação no conjunto da oferta na RMSP, sobretudo, no MSP. Em 2013, 36\% (4.600 UHs) desses produtos estavam concentrados na Capital; em 2015, 46\% (5.200 UHs); e, em 2018, $71 \%$ (15.500 UHs).

b) 0 preço dos produtos do segmento econômico, antes do lançamento do PMCMV (2009), equivalia a US\$100 mil, enquanto o teto do SFH/FGTS era de R\$350 mil. Em 2009, com o PMCMV surge um "novo" produto econômico com valor unitário inferior, de R\$130 mil, inicialmente, passando para $\mathrm{R} \$ 170 \mathrm{mil}$, em 2011, e R\$190 mil, em 2013, que foi classificado como "supereconômico". Assim, o produto "mais caro" do segmento econômico perde espaço para esse "novo" produto e tem seu preço redefinido, alcançando $\mathrm{R} \$ 350 \mathrm{mil}$ em 2015 (equivalente a US\$100 mil), quando 
Gráfico 2 - Estratificação dos preços médios nominais das unidades lançadas na RMSP, na MSP e em outros municípios entre 2013 e 2018
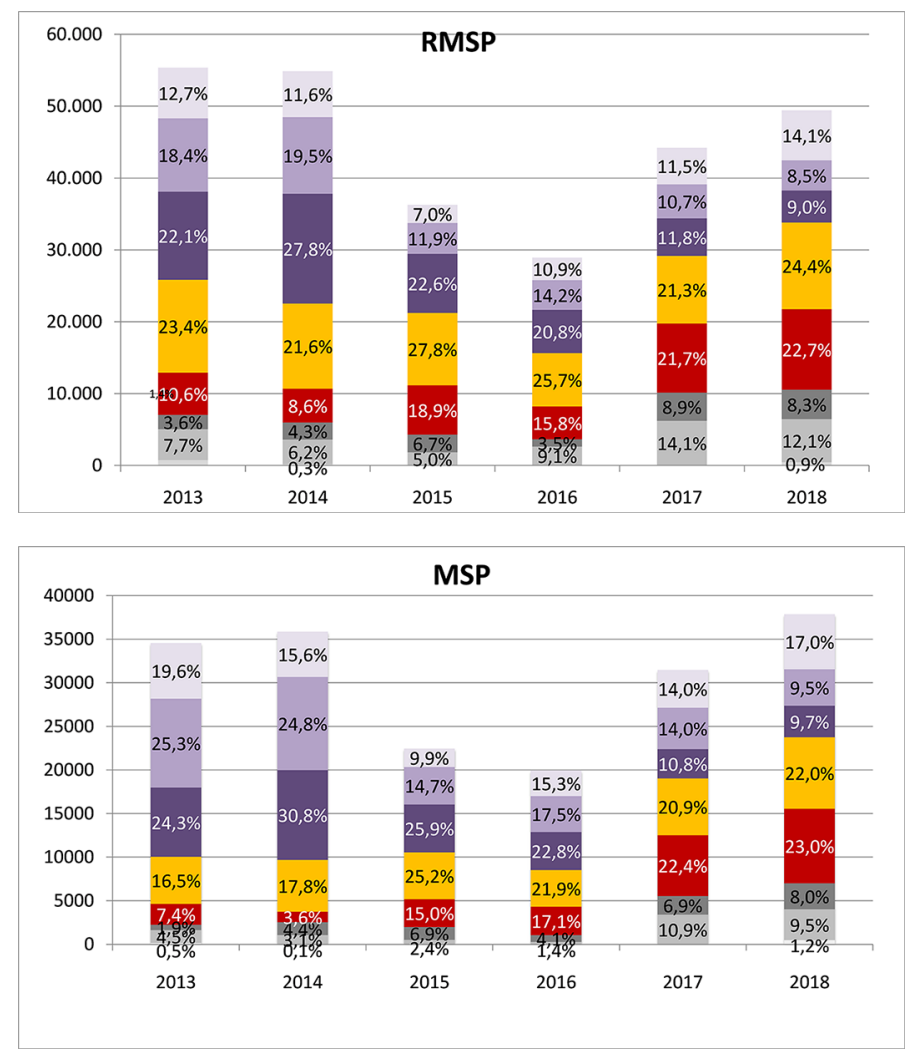

III $>$ R\$750 mil

$=\mathrm{R} \$ 500 \mathrm{mil}-\mathrm{R} \$ 750 \mathrm{mil}$

a $R \$ 350 \mathrm{mil}-\mathrm{R} \$ 500 \mathrm{mil}$

= $\mathrm{R} \$ 225 \mathrm{mil}-\mathrm{R} \$ 350 \mathrm{mil}$

- $R \$ 190 \mathrm{mil}-\mathrm{R} \$ 225 \mathrm{mil}$

- $R \$ 170 \mathrm{mil}-\mathrm{R} \$ 190 \mathrm{mil}$

= $\mathrm{R} \$ 130 \mathrm{mil}-\mathrm{R} \$ 170 \mathrm{mil}$

In $\mathbf{R} \$ 65 \mathrm{mil}-\mathrm{R} \$ 130 \mathrm{mil}$

a $\mathrm{R} \$ 52$ mil-R\$ $65 \mathrm{mil}$

a $<\$ 52 \mathrm{mil}$

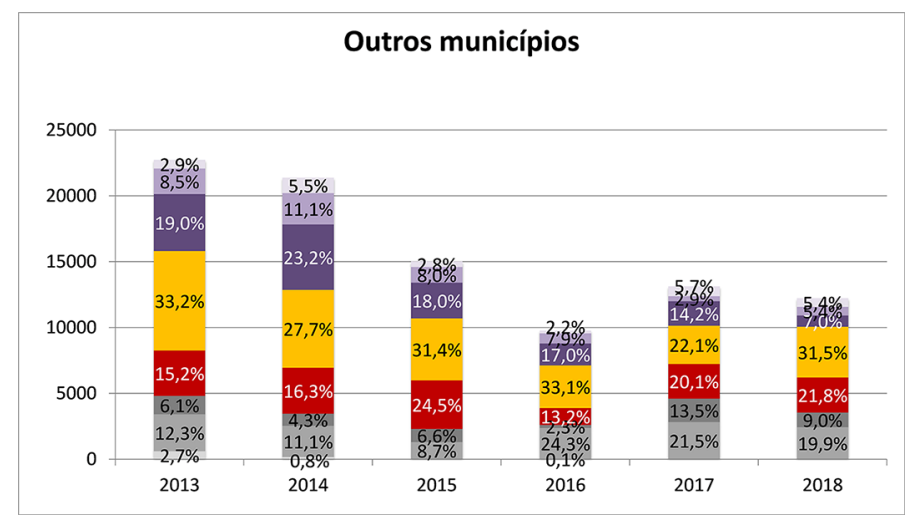

Fonte: Brasil (2019). 
há elevação do teto do PMCMV para $\mathrm{R} \$ 225$ mil, com uma forte desvalorização do real. A partir de 2015, a oferta nas faixas de mercado do PMCMV ganha força, enquanto a do produto "mais caro" do segmento econômico não acompanha essa ampliação. Na RMSP, em 2015, esses produtos representam $28 \%$ (10.100 UHs) e sofrem redução para $24 \%$ (12.100 UHs) em 2018, enquanto, no MSP, são $25 \%$ (5.400 UHs) e caem para $22 \%$ (8.200 UHs). Concomitantemente, na região, os produtos nas faixas 2 e 3 do PMCMV, em 2015, representam 31\% (11.200 UHs) e, em 2018, crescem para 44\% (21.700 UHs), enquanto, no MSP, são $24 \%$ (5.200 UHs) e aumentam para $42 \%$ (15.500 UHs).

c) Até 2014 , a oferta de produtos de preços superiores a $\mathrm{R} \$ 500$ mil apresenta crescimento em sua participação no total da oferta na RMSP em função do aumento dos tetos do financiamento no âmbito do SFH/FGTS ${ }^{6}$ e dos recursos disponíveis no SBPE. A partir de 2015, na RMSP, essa oferta é afetada por uma redução continuada, tendo sua participação de 31\% (17.300 UHs), em 2013, retraída para 19\% (6.800 UHs), mantendo-se, nos anos subsequentes, sempre inferior a 25\% (de 23\% e 11.200 UHs em 2018). No MSP, onde esse produto apresenta maior participação, de 45\% (14.700 UHs) em 2013, verifica-se esse mesmo movimento, pois passa a representar 25\% (5.200 UHs) em 2015 e 26\% (9.800 UHs) em 2018. Fora da Capital, esse produto se fez pouco presente ao longo de todo o período analisado (em torno de $10 \%$ ), alcançando sua participação máxima, em 2014, com 17\% (3.600 UHs). Já os produtos de preços médios, entre $R \$ 350$ mil e $R \$ 500$ mil, apresentam participação relativamente estável até 2016, com pequenas oscilações, variando, na RMSP, em torno de $23 \%$ e, no MSP, de $26 \%$.
Em 2017 e 2018, a participação da oferta desses produtos sofre achatamento, alcançando, respectivamente, $12 \%$ (5.200 UHs) e $9 \%$ (4.500 UHs) na RMSP e 11\% (3.400 UHs) e 10\% (3.600 UHs) no MSP, dada a maior oferta no segmento econômico.

\section{Participação das principais incorporadoras}

Para a construção da análise de alterações e continuidades na participação das principais incorporadoras no período da retração na RMSP, dois movimentos distintos e combinados com relação a volume, localização e preços médios da oferta são considerados. Assim, elabora-se um ranking das principais empresas atuantes nos municípios da região onde houve a retração da oferta; outro, no MSP, onde esta apresenta crescimento; e um terceiro, integrando toda a região que reflete o conjunto dos dois movimentos. Para os três casos, são comparados rankings anuais, de 2015 (último ano do período de desaceleração) e de 2018 (último ano do período de retração).

a) Comparando os rankings das incorporadoras de maior oferta nos outros municípios da RMSP, em 2015 e 2018, confirma-se o predomínio de produtos do segmento econômico mediante uma redução no número de unidades lançadas (de 15.000 UHs para 12.200 UHs) e maior seletividade locacional na oferta de estratos de maior preço. Nesse sentido, voltada quase que exclusivamente para o segmento econômico, em 2018, assiste-se a maior concentração da oferta nas 10 primeiras incorporadoras do ranking ${ }^{7}$ que de $56 \%$, em 2015 , passa para $67 \%$ neste ano. Essas dez empresas respondem por lançamentos cujo preço médio da unidade, de $\mathrm{R} \$ 248 \mathrm{mil}$, apresenta-se bastante inferior ao do conjunto das 
Tabela 3 - Distribuição das unidades e dos VGVs, preços médios no ranking das incorporadoras dos outros municípios, MSP e RMSP (2015 e 2018)

\begin{tabular}{|c|c|c|c|c|c|c|c|c|c|c|c|c|}
\hline & \multicolumn{6}{|c|}{2015} & \multicolumn{6}{|c|}{2018} \\
\hline & UHs & $\begin{array}{c}\% \\
\text { UH }\end{array}$ & $\begin{array}{c}\text { VGV } \\
\text { (em mil) }\end{array}$ & $\begin{array}{c}\% \\
\text { VGV }\end{array}$ & $\begin{array}{l}\text { Preço } \\
\text { Médio } \\
\text { (R\$) }\end{array}$ & $\begin{array}{l}\text { Capital } \\
\text { Aberto }\end{array}$ & UHs & $\begin{array}{c}\% \\
\mathrm{UH}\end{array}$ & $\begin{array}{c}\text { VGV } \\
\text { (em mil) }\end{array}$ & $\begin{array}{c}\% \\
\text { VGV }\end{array}$ & $\begin{array}{l}\text { Preço } \\
\text { Médio } \\
\text { (R\$) }\end{array}$ & $\begin{array}{l}\text { Capital } \\
\text { Aberto }\end{array}$ \\
\hline $10+$ (outros) & 8.370 & 56 & 2.511 .826 & 53 & 300.099 & $2 / 10$ & 8.247 & 67 & 2.048 .285 & 53 & 248.367 & $4 / 10$ \\
\hline Total (outros) & 15.029 & 100 & 4.782 .091 & 100 & 318.191 & -- & 12.232 & 100 & 3.890 .970 & 100 & 318.098 & -- \\
\hline $10+(\mathrm{MSP})$ & 9.238 & 43 & 3.904 .782 & 40 & 422.687 & $5 / 10$ & 19.951 & 54 & 5.619 .684 & 31 & 281.674 & $4 / 10$ \\
\hline Total (MSP) & 21.254 & 100 & 9.748 .076 & 100 & 458.647 & -- & 37.207 & 100 & 18.192 .761 & 100 & 488.961 & -- \\
\hline $10+($ RMSP) & 12.771 & 35 & 4.125 .442 & 28 & 323.032 & $5 / 10$ & 23.498 & 48 & 5.781 .390 & 26 & 246.038 & $3 / 10$ \\
\hline Total (RMSP) & 36.283 & 100 & 14.530 .167 & 100 & 400.468 & -- & 49.439 & 100 & 22.083 .732 & 100 & 446.686 & -- \\
\hline
\end{tabular}

Fonte: Embraesp (2018).

empresas atuantes nos municípios da RMSP, exceto a Capital, de R\$318 mil em 2018, diferindo-se do comportamento de 2015, quando essas médias se aproximam (de $R \$ 300$ mil, das 10+; e de $\mathrm{R} \$ 318$ mil, do total das empresas). Essa diferença notada em 2018 revela a sustentação da oferta pelos recursos disponibilizados pelo PMCMV, nesses municípios. No ranking de 2018, das 10 incorporadoras de maior oferta nesses municípios, quatro são de capital aberto e, à exceção da Helbor, três atuam exclusivamente no segmento econômico (MRV, Tenda e Direcional). No ranking de 2015, são apenas duas (EzTec e Tenda). Apesar da retração da oferta, há um aumento da presença de empresas de capital aberto em 2018, sobretudo daquelas focadas nas faixas de mercado do PMCMV. b) Comparando os rankings das incorporadoras de maior oferta no MSP em 2015 e 2018, confirma-se o crescimento no número de unidades lançadas (de 21.300 UHs para 37.200 UHs), potencializado pela elevação da participação de produtos do segmento econômico. Além disso, em 2018, assiste-se a maior concentração da oferta nas 10 primeiras incorporadoras do ranking ${ }^{8}$ que de $43 \%$, em 2015 , passa para $54 \%$, nesse ano. Por elas oferecerem produtos mais baratos, a concentração do VGV correspondente retrai, de $40 \%$ para $31 \%$. Essas 10 empresas são responsáveis por lançamentos cujo preço médio da unidade, de $\mathrm{R} \$ 282$ mil, é muito menor que o do conjunto do MSP, de R\$490 mil nesse ano, diferindo-se do comportamento de 2015, quando esses valores são mais próximos (de $\mathrm{R} \$ 423$ mil, das $10+$; 
e de $\mathrm{R} \$ 460$ mil, do total das empresas). Essa distinção revela a massiva oferta de produtos econômicos, sobretudo das faixas de mercado do PMCMV, garantindo a retomada do mercado paulistano no período da retração. Em 2018, há uma mudança significativa no perfil das $10+$, em que as cinco primeiras (Plano e Plano, Tenda, Econ, Cury e MRV) oferecem produtos do segmento econômico (até $\mathrm{R} \$ 350$ mil), respondendo por $73 \%$ do volume ofertado por essas empresas, e, destas, quatro, exceto a Econ, voltam-se às faixas de mercado do PMCMV, contribuindo com 60\%. Em 2015, das $10+$, cinco atuam no segmento econômico (Econ, Tenda, Engelux, Yuny e Setin), respondendo por $50 \%$ do volume ofertado por essas empresas, e, destas, apenas a Tenda oferta produtos enquadrados nas faixas de mercado do PMCMV, respondendo por $11 \%$ desse volume. No ranking de 2018, das $10+$, quatro empresas eram de capital aberto: Eztec e Trisul, e do segmento econômico, MRV e Tenda. No ranking de 2015, são cinco empresas de capital aberto: Gafisa, Even, Cyrela e You, atuantes no mercado de médio e alto padrão, e apenas a Tenda no segmento econômico.

c) Devido à expressiva concentração da oferta no MSP em 2018, a análise dos rankings das incorporadoras, na RMSP, acompanha o movimento identificado na Capital e minimiza o arrefecimento da oferta observado nos outros municípios da região, ainda que estes provoquem impactos nos preços médios das UHs e nos VGVs, consoantes com a oferta de produtos muito mais baratos nessas localidades. Comparando os rankings das incorporadoras de maior oferta na RMSP em 2015 e 2018, comprova-se o crescimento no número de unidades lançadas (de 36.300 UHs para 49.400 UHs) com a ascensão da participação de produtos do segmento econômico. Além disso, assiste-se a maior concentração da oferta nas dez primeiras incorporadoras do ranking, ${ }^{9}$ de $35 \%$ em 2015 para 48\% em 2018. Por elas oferecerem produtos de menor preço, não se verifica esse crescimento na participação do VGV correspondente, que se manteve no mesmo patamar, de $28 \%$ em 2015 e $26 \%$ em 2018. Essas 10 empresas lançam unidades cujo preço médio, de $\mathrm{R} \$ 246$ mil, é muito inferior ao do conjunto das empresas atuantes na RMSP, de R\$447 mil em 2018, diferindo-se do comportamento de 2015, quando essas médias apresentam intervalos menores (de $\mathrm{R} \$ 323 \mathrm{mil}$, das $10+$; e de $\mathrm{R} \$ 400$ mil, do total das empresas). Em 2018, há alteração no perfil das 10+, em que as seis primeiras (Plano e Plano, Tenda, MRV, Econ, Cury e Conex), além da Zafir, ofertam produtos do segmento econômico (até $\mathrm{R} \$ 350 \mathrm{mil}$ ), respondendo por $84 \%$ da oferta desse grupo; e, dessas seis, quatro (Plano e Plano, Tenda, Cury e MRV) direcionam-se às faixas de mercado do PMCMV, representando 60\%. Em 2015, das 10+, seis empresas (Asseio, Econ, Tenda, Engelux, Yuny e Plano e Plano) respondem pela oferta no segmento econômico, representando $59 \%$ da oferta desse grupo; e, destas, três (Asseio, Tenda e Plano e Plano) ofertam produtos nas faixas de mercado do PMCMV, correspondendo a 35\%. No ranking de 2018, das 10+, três empresas são de capital aberto: Trisul, além da MRV e Tenda, atuantes no segmento econômico. No ranking de 2015, são cinco empresas de capital aberto: Tenda, do segmento econômico, e Eztec, Gafisa, Even e You, atuantes em mercados de médio e alto padrão. 


\section{O protagonismo dos produtos do segmento econômico na Capital no período de retração da oferta residencial na RMSP}

Do total de 87.400 UHs lançadas no MSP na retração (2016-2018), 50.200 UHs pertencem ao segmento econômico (verticais), representando $57 \%$. Nesse conjunto, verifica-se a predominância de produtos econômicos de até $\mathrm{R} \$ 225$ mil, que apresentam participação crescente ao longo desse último triênio, de 23\%, em 2016, para 43\%, em 2018. Já a oferta de produtos econômicos de preços entre $\mathrm{R} \$ 225$ mil e $\mathrm{R} \$ 350$ mil se manteve estabilizada com participação continuada de $21 \%$, enquanto a de produtos com preços acima de $\mathrm{R} \$ 350 \mathrm{mil}$, majoritária em 2016, representando $56 \%$, sofre descenso e atinge 36\% em 2018.
Destaca-se que, apesar da diversificação de produtos (e preços) no segmento econômico com sua maior presença no MSP na retração, a grande massa de produtos de padrão popular de mercado, incluindo os das faixas 2 e 3 do PMCMV, capitaneou o processo de homogeneização da oferta identificado desde o período de expansão na RMSP.

\section{A concentração do PMCMV na Capital}

Em 2013, o PMCMV alcançou seu maior volume de contratações (912.407 UHs) no Brasil; por sua vez, a RMSP respondeu por apenas $4 \%$, e o MSP, por $1 \%$. Já, em 2016 , quando o Programa apresenta o menor montante de contratações (388.551 UHs), em âmbito nacional, a RMSP e o MSP ampliam suas participações, alcançando $7 \%$ e $3 \%$, respectivamente. A partir desse ano, mesmo com o aumento no volume de contratações no País, a RMSP e o

Gráfico 3 - Número de unidades contratadas no PMCMV no MSP

e em outros municípios da RMSP (2010-2018)

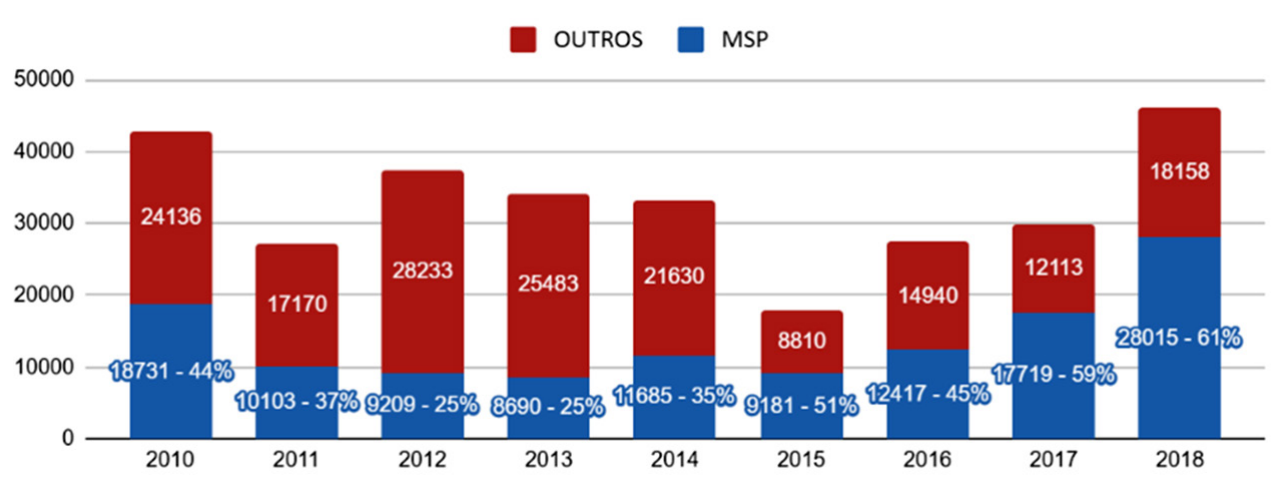

Fonte: Embraesp (2018). 
MSP seguem com participações relativamente ampliadas, atingindo, em 2018 , $9 \%$ e $5 \%$, respectivamente, das 527.115 UHs contratadas no Programa.

A partir de 2016, o MSP passou a apresentar volumes ampliados e participações crescentes no conjunto das unidades contratadas na RMSP. Em 2018, ano de maior número de contratações do PMCMV na região (46.173 UHs), a Capital que respondeu por 45\% (12.417 UHs) das unidades contratadas em 2016, passa a concentrar 61\% (28.015 UHs). Esse movimento também é observado se consideradas as faixas do Programa, exceto a Faixa $1,{ }^{10}$ e a participação do MSP atinge 57\%, com 23.339 UHs contratadas em 2018, o maior montante desde 2010.

Cumpre observar que, para o enquadramento na Faixa 1 do PMCMV, há parâmetros mínimos referentes à área útil da unidade (superior a $35 \mathrm{~m}^{2}$ desde o lançamento do Programa) e ao número de dormitórios (no mínimo dois), o que não ocorre para as Faixas 2 e $3 .{ }^{11}$ Isto, somado à flexibilização da exigência de vagas na legislação municipal, contribui para a explicação do surgimento da oferta de produtos econômicos, com áreas inferiores a $25 \mathrm{~m}^{2}$, de zero a um dormitório, neste contexto de maior participação da Capital nas contratações do Programa.

\section{Características gerais da oferta do segmento econômico na Capital}

O crescimento da oferta de produtos econômicos nas faixas de mercado do PMCMV (até R\$225 mil) ocorre mediante alterações nas características e padrões dos empreendimentos que os viabilizaram em diferentes subtipos de mercado da Capital. Como parte importante dessas mudanças, observa-se um aumento significativo no porte dos empreendimentos, de 154 UHs, em 2016, para 201 UHs, em 2018, com tipos mais adensados e verticalizados de edificações, resultantes de importantes reduções nas dimensões relativas às unidades como no consumo médio de terreno, de $33 \mathrm{~m}^{2}$ para $21 \mathrm{~m}^{2}$; na AU média, de $42 \mathrm{~m}^{2}$ para $39 \mathrm{~m}^{2}$; e na AT média, de $76 \mathrm{~m}^{2}$ para $67 \mathrm{~m}^{2}$, em decorrência da retirada parcial de vagas. Em 2016, $41 \%$ das unidades lançadas nessa faixa de preço não possuía vagas e, em 2017 e 2018, esse percentual saltou para $73 \%$.

Embora a oferta de produtos econômicos na faixa de preços entre $R \$ 225$ mil e $R \$ 350$ mil tenha se mantido estável, bem como o porte dos empreendimentos, em torno de 130 UHs, observam-se mudanças ainda mais acentuadas que nos produtos econômicos mais baratos, relacionadas às características das unidades, como a redução expressiva do consumo de terreno por unidade, de $37 \mathrm{~m}^{2}$, em 2016, para $14 \mathrm{~m}^{2}$, em 2018, bem como da AU média, de $44 \mathrm{~m}^{2}$ para $37 \mathrm{~m}^{2}$; e da AT média, de $83 \mathrm{~m}^{2}$ para $69 \mathrm{~m}^{2}$, em decorrência da redução parcial das vagas. Entre 2016 e 2018, a participação das unidades com uma vaga decresce de $86 \%$ para $58 \%$, enquanto a das unidades sem vaga passa de $9 \%$ para $42 \%$. Destaca-se que as unidades no segundo estrato, que eram maiores que as do primeiro em 2016, ficam muito menores em 2018, invertendo essa relação.

Essas alterações nas características dos empreendimentos econômicos, no entanto, redundam em comportamentos distintos dos preços médios do $\mathrm{m}^{2}$ da AU nos dois estratos. Enquanto, no primeiro estrato, os preços médios da AU mantêm-se em torno de $\mathrm{R} \$ 4.800$, no segundo, eles crescem $10 \%$, de $R \$ 6.300$ para $\mathrm{R} \$ 7.000$, entre 2016 e 2018. Isto revela uma 
inovação no segmento econômico com a incorporação de um "novo" produto, os chamados "compactos", que atrai demanda diferenciada nos subtipos de mercado consolidados da Capital e se distribui entre os dois estratos, apesar de se concentrar mais no segundo.

A diversificação dos produtos econômicos na retração resulta de estratégias produtivas, mercantis e financeiras condicionadas pela disponibilidade de financiamento. E essa diversificação, definida pelas empresas, envolve a decisão sobre o destino dos recursos disponíveis em determinado momento, a localização, o porte dos empreendimentos, o padrão e os preços das unidades. Na retração, as principais empresas do ranking dão continuidade à tendência de massificação e homogeneização da oferta, capitaneada por produtos econômicos populares, enquanto outras empresas se utilizam de estratégias inovadoras no desenho de seus empreendimentos, introduzindo os produtos compactos, cujos preços médios, muitas vezes, enquadram-se no teto das faixas de mercado do PMCMV, para alavancarem empreendimentos mistos que incluem unidades mais caras, de outros padrões.

\section{Considerações finais}

A análise elaborada sobre o comportamento da oferta residencial na RMSP no período de retração (2016-2018) revela um reposicionamento quanto à localização e às características dos produtos ofertados, com a retomada do protagonismo da Capital, cuja concentração alcança percentual semelhante a 2006, no pré-boom, e volume semelhante ao de 2010, no boom. Isto é evidenciado pelo encolhimento dos vetores de expansão na região em direção à Capital e pela participação maior no conjunto da oferta de subtipos de mercado consolidados e emergentes, majoritariamente localizados no MSP, como Sé, Mooca, Butantã e Pinheiros, além de Pirituba e Itaquera. Assim, vetores importantes no conjunto dos lançamentos da RMSP, articulados a mercados tradicionalmente fortes, como Guarulhos, São Bernardo e Santo André, apresentam encolhimento. Concomitantemente, os dois únicos vetores que não são afetados se situam a oeste, englobando Barueri, Cotia e Osasco, este último ainda apresentando crescimento. Outras evidências desse reposicionamento estão na opção por um maior adensamento e verticalização nos empreendimentos, potencializados pela redução do tamanho das unidades e do número de vagas e, também, por preços médios das unidades menores, que não são acompanhados, em mesma intensidade, pelos da AU e da AT.

Tais alterações respondem aos condicionantes do financiamento disponível e às estratégias de maximização de ganhos das empresas, em contexto de redução de crédito para unidades mais caras, conduzindo a um direcionamento do setor ao segmento econômico com a sua localização no MSP, em grande medida ancorado no crescimento da oferta nas faixas de mercado do PMCMV, voltada ao estrato popular. Porém, a tendência de homogeneização da oferta capitaneada pelo segmento econômico verificada no período de expansão, quando esteve majoritariamente nos outros municípios da RMSP, assume novas configurações, especialmente pela diversificação de produtos, incluindo os chamados "compactos" e sua inserção em "novas" localidades. Essa diversificação é engendrada por expectativas de 
ganhos futuros e alavancagem de valorização imobiliária, apoiando-se em oportunidades variadas com potencial de atração a investidores e grupos sociais menos suscetíveis à perda de rendimentos e, ainda, solvabilizados pelo financiamento disponível.

Após 2018, constata-se a continuidade dos dois movimentos que marcam o período de retração na RMSP, de crescimento da oferta e de sua concentração no MSP, com a participação ampliada do segmento econômico, e de declínio nos outros municípios, conforme os balanços do Secovi-SP para 2019 e 2020, com base no banco de dados da Embraesp.

Porém, com as mudanças na disponibilidade de recursos das principais fontes de financiamentos com a recuperação no SBPE, a partir de 2019 , e sem a perspectiva de crescimento do FGTS (mediante o crescente desemprego e retirada dos benefícios), questiona-se a exigência de um novo reposicionamento da oferta na RMSP a partir de 2021. Esse reposicionamento poderá, ainda, ser afetado por mudanças em âmbito nacional, tais como: a criação de linhas de financiamento com adoção de juros variáveis e o lançamento do Programa Casa Verde e Amarela, sem previsão de recursos provenientes do OGU. Como consequência do novo cenário, já podem ser observados movimentos das empresas do setor na busca de outras fontes de recursos, mediante a expansão da financeirização do setor imobiliário com novas rodadas de Ofertas Públicas Iniciais (OPIs) das empresas e a utilização crescente de instrumentos financeiros de transformação de dívidas imobiliárias em ativos financeiros.

Considerando os limites da abordagem trazida nesta oportunidade, e sem esgotar os temas apresentados, lançam-se problematizações para aprofundamento futuro da análise, em face da sua importância e atualidade no cenário de acirramento da crise atual, em suas múltiplas dimensões: sanitária, ambiental, urbana, social e econômica.

Chamam a atenção duas questões relacionadas ao papel do Estado na esfera do financiamento e na governança metropolitana em contexto de avanços da financeirização urbana (Klink e Souza, 2017). Suscita-se uma discussão sobre o financiamento público e os subsídios que se entrelaçam com circuitos rentistas e financeirizados, condicionando a oferta e sua distribuição no âmbito do PMCMV, como observado nos empreendimentos lançados nos subtipos de mercado (consolidados e emergentes) da Capital, na retração. E problematizam-se as limitações do planejamento e gestão municipais e a incipiência de uma governança metropolitana que, segundo Maricato (2011b), ficou "no limbo", diante de uma metrópole "com-fusa", que acomoda lógicas rentistas patrimonialistas e financeirizadas (Abramo, 2007; Rolnik, 2015) e importantes mudanças socioespaciais multiescalares. Tais condições se intensificam adiante da inflexão de políticas ultraliberais (Ribeiro, 2020) e do avanço da dominância financeira na produção do espaço urbano (Fix e Paulani, 2019). As ingerências do setor imobiliário na provisão da moradia e nos destinos das cidades, bem como nas condições de acesso ao financiamento com fundos públicos, impõem obstáculos ao enfrentamento dos problemas de grandes centros urbanos e regiões metropolitanas, relacionados, em grande medida, ao insuficiente controle por parte do Estado e da sociedade sobre os processos de valorização especulativa da terra e dos bens imóveis, agora alçados à condição de ativos financeiros. 


\section{[I] https:// orcid.org/0000-0002-1828-7615}

Universidade Federal de São Carlos, Programa de Pós-Graduação em Engenharia Urbana. São Carlos, SP/Brasil.

carolmcastro@gmail.com

\section{[II] https:// orcid.org/0000-0002-7754-6533}

Universidade São Judas Tadeu, Faculdade de Arquitetura e Urbanismo, Programa de Pós-Graduação em Arquitetura e Urbanismo. São Paulo, SP/Brasil.

lesigolo@gmail.com

\section{Notas}

(1) A RMSP é formada por 39 municípios, divididos em cinco sub-regiões: Norte: Caieiras, Cajamar, Francisco Morato, Franco da Rocha e Mairiporã; Leste: Arujá, Biritiba-Mirim, Ferraz de Vasconcelos, Guararema, Guarulhos, Itaquaquecetuba, Mogi das Cruzes, Poá, Salesópolis, Santa Isabel e Suzano; Sudeste: Diadema, Mauá, Ribeirão Pires, Rio Grande da Serra, Santo André, São Bernardo do Campo e São Caetano do Sul; Sudoeste: Cotia, Embu, Embu-Guaçu, Itapecerica da Serra, Juquitiba, São Lourenço da Serra, Taboão da Serra e Vargem Grande Paulista; Oeste: Barueri, Carapicuíba, Itapevi, Jandira, Osasco, Pirapora do Bom Jesus e Santana de Parnaíba.

(2) O MSP é subdividido em 32 subprefeituras: Aricanduva, Butantã, Campo Limpo, Capela do Socorro, Casa Verde, Cidade Ademar, Cidade Tiradentes, Ermelino Matarazzo, Freguesia do Ó/Brasilândia, Guaianases, Ipiranga, Itaim Paulista, Itaquera, Jabaquara, Jaçanã/Tremembé, Lapa, M’Boi Mirim, Mooca, Parelheiros, Penha, Perus, Pinheiros, Pirituba, Santana/Tucuruvi, Santo Amaro, São Mateus, São Miguel Paulista, Sapopemba, Sé, Vila Maria/Vila Guilherme, Vila Mariana e Vila Prudente.

(3) O PMCMV foi lançado em 2009 (LF n. 11.977/2009), com o objetivo de produzir, inicialmente, um milhão de unidades, distribuídas em três faixas, definidas segundo renda familiar e valor máximo da unidade. Para cada faixa, foram definidos distintos subsídios e descontos, mobilizando recursos não onerosos do Orçamento Geral da União (OGU), além do Fundo de Arrendamento Residencial (FAR) e do Fundo de Garantia por Tempo de Serviço (FGTS).

(4) No ranking das 10+ subprefeituras de 2010-2012 comparecem: Mooca (10\%), Campo Limpo (9\%), Sé (9\%), Pinheiros (7\%), Lapa (7\%), Santo Amaro (6\%), Vila Mariana (5\%), Ipiranga (5\%), Aricanduva/Vila Formosa/Carrão (5\%) e Butantã (5\%); e no de 2016-2018: Sé (13\%), Pirituba (10\%), Mooca (9\%), Butantã (8\%), Pinheiros (8\%), Vila Mariana (7\%), Campo Limpo (6\%), Lapa (6\%), Itaquera (5\%) e Penha (4\%).

(5) No ranking dos 10+ municípios de 2010-2012 comparecem: Guarulhos (22\%), Barueri (11\%), São Bernardo (10\%), Santo André (8\%), Mogi das Cruzes (8\%), Osasco (6\%), Diadema (6\%), São Caetano (5\%), Cotia (4\%), Taboão da Serra (3\%) e no de 2016-2018: Osasco (20\%), Guarulhos (16\%), Barueri (11\%), Cotia (10\%), Santo André (6\%), Mauá (6\%), Diadema (5\%), São Bernardo (4\%), Suzano (3\%) e Jandira (2\%). 
(6) Elevação dos valores máximos de unidades para financiamento no SFH-FGTS: fev 2005 - R\$350 mil / mar 2009 - R\$500 mil / set 2013 - R\$750 mil / nov 2016 - R\$950 mil / jul $2018-R \$ 1,5$ milhões. Considera-se que a elevação do teto do SFH/FGTS, em 2013, está alinhada com a valorização das condições de produção resultante da expansão da oferta (insumos da construção, terrenos, mão de obra); já a elevação, em 2016, em contexto de retração da oferta, pode ser explicada pela pressão decorrente da elevação da taxa Selic, quando esta alcança seus mais elevados patamares (dez 2015 até ago 2016 - 14,15\%). A partir de então, com uma crise político-institucional, com o impeachment da presidenta Dilma, inicia-se uma política de redução da taxa básica de juros. Ao longo de 2017, a taxa reduz-se à metade, fechando o ano em 6,90\%. Nesse momento, há também elevação dos tetos do PMCMV no início da Fase 3 (em out 2015). Elevação dos tetos do MCMV (faixas de mercado): jul 2009 - R\$130 mil / fev 2011 - R\$170 mil / out $2012-\mathrm{R} \$ 190 \mathrm{mil}$ / out $2015-\mathrm{R} \$ 225$ mil.

(7) No ranking das 10+ incorporadoras nos outros municípios da RMSP, em 2015, constam: A. C. C. T. Asseio; Eztec; Masa; Tenda; Plano e Plano; Zatz; RVE; Living; MZM e NHZ; e, em 2018: Conex Cooperativa; MRV; Zafir; Tenda; Direcional; Helbor; Zatz; GER; Big e Hoga.

(8) No ranking das 10+ incorporadoras no MSP, em 2015, constam: Gafisa; Econ; Tenda; Engelux; Yuny; Even; You; Cyrela; Diálogo e Setin; e; em 2018: Plano e Plano; Tenda; Econ; Cury; MRV; Vitacon; Living; Trisul; One e Eztec.

(9) No ranking das 10+ incorporadoras na RMSP, em 2015, constam: Ez Tec; A. C. C. T. Asseio; Tenda; Gafisa; Econ; Engelux; Yuny; Plano e Plano; Even e You; e, em 2018: Plano e Plano; Tenda; MRV; Econ; Cury; Conex; Vitacon; Trisul; Living e Zafir.

(10) Esse pico de volume de contratações observado em 2018, nas demais faixas, não foi reproduzido na Faixa 1, pois esta apresenta uma sequência de oscilações intensas (em 2012, 2013 e 2014, alcança os maiores volumes anuais, superiores a 12 mil UHs, enquanto, em 2011, 2015 e 2017, apresenta patamares inferiores a $2.700 \mathrm{UHs}$ ).

(11) Normas que estabelecem parâmetros para imóveis financiados com recursos do FAR e Fundo de Desenvolvimento Social (FDS) no âmbito do PMCMV - portaria n. 660, de 14/11/2018. Normas que estabelecem parâmetros para imóveis financiados com recursos do FGTS no âmbito do PMCMV - portaria MCid n. 363 de 11/8/2011, portaria MCid n. 570 de 29/11/2016 e portaria n. 1.735 de 16/7/2019. 


\section{Referências}

ABRAMO, P. (2007). A cidade COM-FUSA: a mão inexorável do mercado e a produção da estrutura urbana nas grandes metrópoles latino-americanas. Revista Brasileira de Estudos Urbanos e Regionais, v. 9, n. 2, pp. 25-54.

BALL, M. (1986). Housing analysis: time for a theoretical refocus? Housing Studies, v. 1, n. 3, pp. 147-165.

BRASIL (2019). Base de dados em excel das contratações do Programa Minha Casa Minha Vida no Brasil. Brasília, Ministério do Desenvolvimento Regional/Secretaria Nacional de Habitação.

CARLOS, A. F. (2007). O espaço urbano. Novos escritos sobre a cidade. São Paulo, FFLCH.

CASTRO, C. M. P. (1999). A explosão do autofinanciamento na produção da moradia em São Paulo nos anos 90. Tese de Doutorado. São Paulo, Universidade de São Paulo.

CASTRO, C. M. P. de; SHIMBO, L. Z. (2011). O "Padrão Econômico" da habitação: construindo uma trajetória de mercado. In: XIV ENCONTRO NACIONAL DA ANPUR. Anais... Rio de Janeiro, Anpur.

EMBRAESP (2018). Banco de Dados de Lançamentos de Empreendimentos Residenciais na RMSP. São Paulo, Empresa Brasileira de Estudos do Patrimônio.

FIX, M. B.; PAULANI, L. M. (2019). Considerações teóricas sobre a terra como puro ativo financeiro e o processo de financeirização. Revista de Economia Política, v. 39, n. 4(175), pp. 638-657.

KLINK, J. J.; SOUZA, M. B. (2017). Financeirização: conceitos, experiências e a relevância para o campo do planejamento urbano brasileiro. Cadernos Metrópole. SãoPaulo, v. 19, n. 39, pp. 379-406.

LEFEBVRE, H. (1973). A re-produção das relações de produção. Publicações Escorpião, Porto, Antaropos.

MARICATO, E. (1984). Política habitacional e indústria da construção. Tese de Doutorado. São Paulo, Universidade de São Paulo.

(2011a). O impasse da política urbana no Brasil. São Paulo, Vozes.

(2011b). Metrópoles desgovernadas. Estudos Avançados, v. 25, n. 71, pp. 7-22.

MIOTO, B. T.; PENHA FILHO, C. A. (2018). Crise econômica e o setor imobiliário no Brasil: um olhar a partir da dinâmica das maiores empresas de capital aberto (Cyrela, PDG, Gafisa e MRV). In: I SEMINÁRIO FINANCEIRIZAÇÃO E ESTUDOS URBANOS: OLHARES CRUZADOS EUROPA E AMÉRICA LATINA. Anais... São Carlos, IAU/USP.

MIOTO, B. T.; CASTRO, C. M. P.; SÍGOLO, L. M. (2019). Expansão e desaceleração do mercado privado formal de moradia a partir dos anos 2000 na Região Metropolitana de São Paulo. Cadernos Metrópole. São Paulo, v. 21, n. 44, pp. 253-280.

RIBEIRO, L. C. Q. (2020). As metrópoles e o direito à cidade na inflexão ultraliberal da ordem urbana brasileira. Texto para Discussão n. 12. Disponível em: https://www.observatoriodasmetropoles. net.br/wp-content/uploads/2020/01/TD-012-2020_Luiz-Cesar-Ribeiro_Final.pdf. Acesso em: 20 dez 2020.

ROLNIK, R. (2015). Guerra dos lugares. A colonização da terra e da moradia na era das finanças. São Paulo, Boitempo. 
RUFINO, M. B. C. (2019). Ascensão da Associação Brasileira de Incorporadoras (Abrainc) na financeirização do setor imobiliário habitacional. In: XVIII ENCONTRO NACIONAL DA ANPUR. Anais... Natal, EDUFRN.

SíGOLO, L. M. (2014). O boom imobiliário na metrópole paulistana: o avanço do mercado formal de moradia em direção à periferia e a nova cartografia da segregação socioespacial. Tese de Doutorado. São Paulo, Universidade de São Paulo.

SILVA, H. M. B. (coord.). (2015). Características da produção imobiliária formal nos anos 2000 e seus efeitos sobre o custo e condições de habitação na Região Metropolitana de São Paulo. São Paulo, Lincoln Institute of Land Policy.

SINDICATO DA HABITAÇÃO-SP (2020). Anuário do Mercado Imobiliário/2019. Disponível em: http:// www.secovi.com.br/downloads/url/2540. Acesso em: 20 dez 2020.

(2021). Mercado Imobiliário da Cidade de São Paulo 2020. Disponível em: https://www.secovi. com.br/downloads/url/2568. Acesso em: 20 dez 2020.

VARGAS, N. (1983). "Racionalidade e não racionalização: o caso da construção habitacional". In: FLEURY, A. C. C.; VARGAS, N. (orgs.) Organização do trabalho. São Paulo, Atlas. 
